\title{
TRANSFORMAÇÃO GENÉTICA DE CITROS COM OS GENES BACTERIOPSINA (bO), CECROPINA E GUS
}

\section{FERNANDo AlVES DE AZEVEDo}

Tese apresentada à Escola Superior de Agricultura "Luiz de Queiroz" da Universidade de São Paulo, para obtenção do título de Doutor em Agronomia, Área de Concentração: Fitotecnia.

PIR A CI C A B A

Estado de São Paulo - Brasil

Maio - 2005 


\title{
TRANSFORMAÇÃO GENÉTICA DE CITROS COM OS GENES BACTERIOPSINA (bO), CECROPINA E GUS
}

\author{
Fernando Alves de AzeVedo \\ Engenheiro Agrônomo
}

Orientador: Prof. Dr. FRANCISCO DE ASSIS ALVES MOURÃO FILHO

\begin{abstract}
Tese apresentada à Escola Superior de Agricultura "Luiz de Queiroz" da Universidade de São Paulo, para obtenção do título de Doutor em Agronomia, Área de Concentração: Fitotecnia.
\end{abstract}

P IR A CI CA B A

Estado de São Paulo - Brasil

Maio - 2005 
Dados Internacionais de Catalogação na Publicação (CIP) DIVISÃO DE BIBLIOTECA E DOCUMENTAÇÃO - ESALQ/USP

\section{Azevedo, Fernando Alves de}

Transformação genética de citros com os gene bacteriopsina $(b O)$, cecropina e gus / Fernando Alves de Azevedo. - - Piracicaba, 2005.

76 p. : il.

Tese (doutorado) - - Escola Superior de Agricultura Luiz de Queiroz, 2005. Bibliografia.

1. Agrobacterium 2. Cancro cítrico 3. Clorose variegada dos citros 4. Gomose 5. Resistência genética vegetal 6 . Transformação genética I. Título 


\section{OFEREÇO}

A Deus, pois....

“Há diferentes atividades, mas um mesmo é Deus que realiza todas as coisas em todos. A cada um é dada a manifestação do Espírito em vista do bem comum. A um é dada a palavra de sabedoria e a outro a de ciência segundo o mesmo Espírito” (1Cor 12, 6-9)

.....por isso cada um tem um dom, que deve ser respeitado, preservado e posto em prática em toda sua grandeza, para o benefício de todos.

Aos meus pais

\section{JOSÉ JAIME e FÁTIMA REGINA}

"Que me deram a vida e me ensinaram a vivê-la com dignidade; iluminaram meus caminhos com afeto e dedicação, para que trilhasse sem medo e cheio de esperança; e, se doaram inteiros renunciando aos seus sonhos, para que muitas vezes pudesse realizar os meus.” (autor desconhecido)

À irmã Adriana e os irmãos Ricardo,

Renato e suas respectivas famílias. 


\section{AGRADECIMENTOS}

À Escola Superior de Agricultura 'Luiz de Queiroz' da Universidade de São Paulo, pela oportunidade oferecida no curso de doutorado em Fitotecnia;

A Coordenadoria de Aperfeiçoamento em Pesquisa de Ensino Superior pela concessão de bolsa de estudos;

Ao Prof. Dr. Francisco de Assis Alves Mourão Filho pela dedicada orientação e o exemplo de profissionalismo;

À Profa. Dra Beatriz Madalena Januzzi Mendes (co-orientadora) pela constante ajuda na elaboração deste trabalho;

Aos doutores Ricardo Harakava (Instituto Biológico - São Paulo) e Eric Lam (The State University of New Jersey - USA) pela contribuição durante a realização e discussão deste trabalho;

À Dra. Helaine Carrer (CBTEC - ESALQ/USP), seus orientados Simone Guidetti Gonzalez, Adriano Reis Lucheta, Carlos Francisco Ragassi, e a Dra. Silvana A. Creste Dias de Souza (Pós-doutoranda Cena/USP) pela ajuda nas análises moleculares;

Ao MSc. Eduardo Feichtenberger (UPD de Sorocaba, APTA Regional, SAA) que nos cedeu isolados de Phytophthora nicotianae para realização dos bioensaios;

Ao MSc. Rock Seille Carlos Christiano (Doutorando Fitopatologia ESALQ/USP) pela contribuição na instalação, condução e avaliação do experimento com cancro cítrico;

Aos ‘irmãos’ de república: Gustavo, Júnior e Hector pelos ótimos momentos compartilhados. E aos novos e ex-integrantes: Miguel, Cláudio, Jovan e Juanito, obrigado pela amizade diária;

Aos amigos Alexandra, Dayse, Evandro, Márcia, Rafael e Weliton pelos bons, produtivos e divertidos momentos vividos juntos no Laboratório de Biotecnologia de Plantas Hortícolas;

A todos estagiários(as) do Laboratório de Biotecnologia de Plantas Hortícolas, em especial a Fabrízzio (Fantástiko), Luis Gustavo (Gusmão), Leandro (Batatinha), 
Fábio (Si-viu) e André (Sapateiro) pela amizade e incentivo durante todo o doutorado;

Às amigas Maria Cecília e Carol, sempre presentes, com conselhos e palavras confortantes, nos momentos mais difíceis;

À Edileuza, Marli e Dona Helena pelo convívio diário e amizade;

À secretária do curso de Pós-Graduação em Fitotecnia, Luciane Lopes que foi sempre amiga, incentivando e participando de toda a trajetória no doutorado;

Aos amigos do Laboratório de Biotecnologia de Vegetal do Cena: Jannayna, Maria Graziela (Zizi), Liliane (Lili), Renata, Hérika, Raquel, Joyce, Flávio, Júnior e Cantídio pelos bons momentos vividos juntos e pela ajuda concedida.

Aos funcionários do Departamento de Produção Vegetal (ESALQ/USP) eamigos Éder, Davi e Sr. José pela grandiosa contribuição no desenvolvimento deste trabalho.

A todos os pesquisadores e funcionários do Centro APTA Citros 'Sylvio Moreira’ do Instituto Agronômico pela prestativa ajuda e receptividade.

Finalmente, a todos que, de algum modo, tenham contribuído para a realização deste trabalho. 
LISTA DE FIGURAS............................................................................. ix

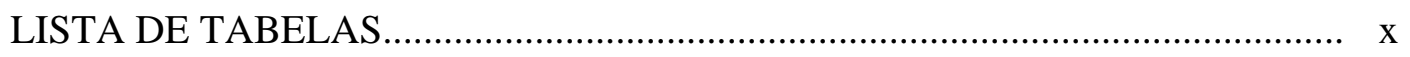

LISTA DE ABREVIATURAS..................................................................

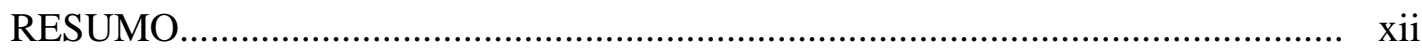

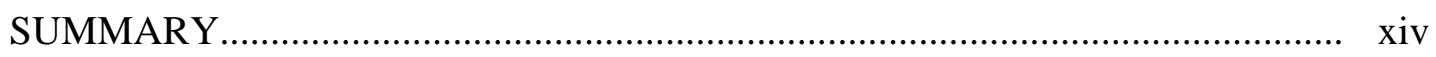

1 INTRODUÇÃ

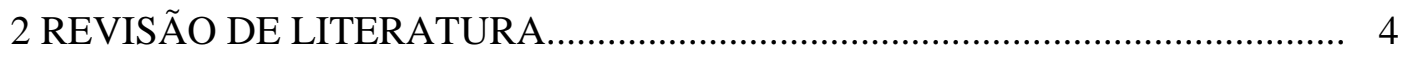

2.1 Aspectos gerais do gênero Citrus............................................................... 4

2.2 Doenças importantes na citricultura brasileira................................................. 6

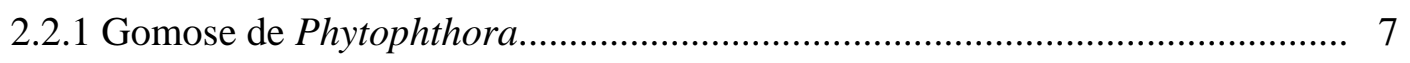

2.2.2 Clorose variegada dos citros e cancro cítrico................................................. 9

2.3 Transformação genética......................................................................... 11

2.3.1 Aspectos Gerais.............................................................................. 11 


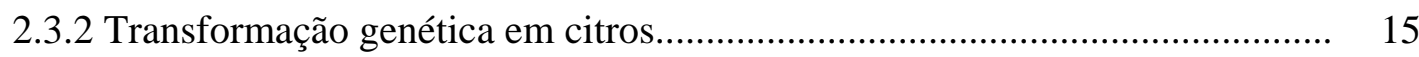

2.4 Transformação genética visando resistência a doenças................................... 17

2.4.1 Genes que estimulam o sistema de defesa das plantas................................ 18

2.4.2 Peptídeos antimicrobianos................................................................. 20

2.4.3 Expressão de genes no xilema................................................................. 22

2.5 Considerações Finais.............................................................................. 24

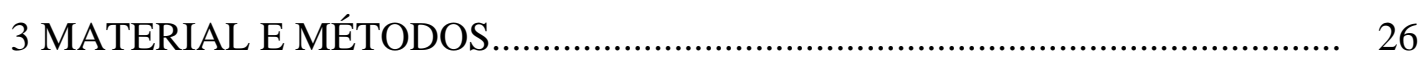

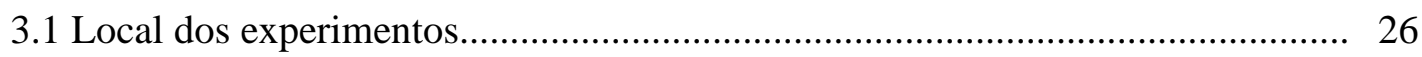

3.2 Transformação genética de citros............................................................... 26

3.2.1 Origem, preparação e regeneração do material vegetal..................................... 26

3.2.2 Linhagem de Agrobacterium utilizada nos experimentos............................. 27

3.2.3 Manutenção e cultivo de Agrobacterium tumefaciens.................................... 30

3.2.4 Inoculação e co-cultivo.......................................................................... 30

3.2.5 Seleção e regeneração de plantas................................................................ 31

3.2.6 Teste histoquímico GU e análises moleculares.......................................... 31

3.2.7 Microenxertia e aclimatização das plantas.................................................... 32

3.2.3 Avaliação de resistência a Phytophthora nicotianae........................................ 33

3.3 Avaliação de resistência a Phythophtora nicotianae em plantas transgênicas de limão ‘Cravo’ transformadas geneticamente com o gene $b O \ldots \ldots \ldots \ldots \ldots \ldots \ldots \ldots \ldots . . . . . . . . . . . . . . . . .33$

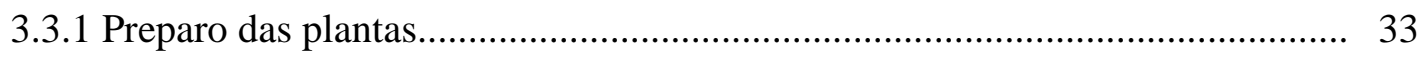

3.3.2 Obtenção, seleção do inóculo e instalação do bioensaio................................... 34 
3.4 Avaliação de resistência a Xanthomonas axonopodis pv. citri em folhas destacadas de laranja 'Valência' transformadas com o gene cecropina

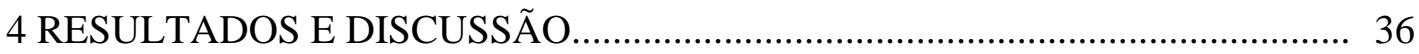

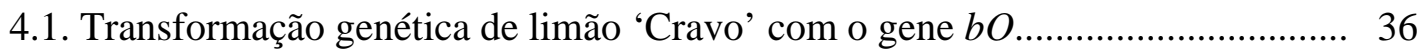

4.1.1 Regeneração de brotos e confirmação da transformação.................................. 36

4.1.2 Avaliação de resistência a Phythophtora nicotianae ....................................... 39

4.2 Transformação genética de laranja doce com o gene cecropina......................... 42

4.2.1 Regeneração dos brotos e confirmação da transformação................................ 42

4.2.2 Avaliação de resistência a Xanthomonas axonopodis pv. citri em folhas destacadas de laranja 'Valência' transformadas com o gene cecropina........... 46

4.3 Transformação genética de Citrus sinensis com o promotor da fenilalamina amônia-liase isolado de laranja doce

4.3.1 Regeneração de brotos................................................................................... 50

4.3.2. Expressão do gene Gus............................................................................. 51

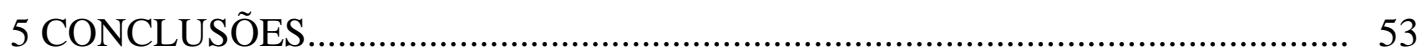

REFERÊNCIAS BIBLIOGRÁFICAS.......................................................... 54

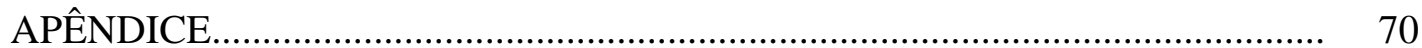




\section{LISTA DE FIGURAS}

Página

1 Representação esquemática da construção utilizada nos experimentos de transformação de limão 'Cravo', com o gene bO, via Agrobacterium tumefaciens... 27

2 Representação esquemática do plasmídeo pCAMBIA 2201 contendo o gene da cecropina, utilizado para as transformações das variedades copa de laranja doce.

3 Construção utilizada para a transformação genética de laranja doce, utilizando o plasmídeo pCAMBIA 2201, com o promotor PAL de Citrus sinensis e o gene gus......

4 Análises: histoquímica de Gus, PCR e Southern e Northern blot nas plantas transgênicas de limão 'Cravo'..

5 Planta de limão 'Cravo' transgênica (esquerda) e detalhes das folhas mostrando lesões de hipersensibilidade relacionadas com a expressão do gene $b O$ (direita)......................................................................................................... 38

6 Variações no tamanho das lesões de $P$. nicotianae em hastes de limão 'Cravo'....... 41

7 Transformação genética de laranja doce com o gene cecropina a partir de tecido

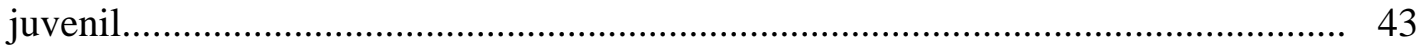

8 Análise de PCR de brotos de laranja doce transformadas com o gene cecropina...... 45

9 Detecção do gene cecropina via 'Southern blot' em plantas da variedade 'Valência'......................................................................................................... 45

10 Período médio de incubação (incidência), em dias, para o aparecimento dos primeiros sintomas de cancro cítrico em folhas de plantas de laranja 'Valência'...... 47

11 Porcentagem da área da folhas de laranja 'Valência' lesionada sobre o total da área foliar (severidade)........................................................................................... 47

12 Diferentes níveis de severidade nas lesões de cancro cítrico entre folha de planta transgênica (esquerda) e de planta não transformada (direita)................................. 48

13 Seqüência da transformação de laranja doce com o gene gus com o promotor PAL. 52 


\section{LISTA DE TABELAS}

Página

1 Comprimento, largura e presença de goma, nas lesões de $P$. nicotianae em plantas de limão 'Siciliano'

2 Porcentagem de plantas com goma, comprimento $(\mathrm{cm})$ e área $\left(\mathrm{cm}^{2}\right)$ das lesões causadas por $P$. nicotianae no lenho de plantas de limão 'Cravo'.

3 Número de gemas adventícias desenvolvidas, total de brotos PCR+, eficiência de transformação e total de plantas transgênicas de laranja doce transformadas com o gene cecropina.

4 Número de brotos de laranja 'Valência' regenerados e PCR positivo para o gene gus dirigido pelo promotor da fenilalamina amônia-liase. 


\section{LISTA DE ABREVIATURAS}

atta Gene atacina isolado de Hyalophia cecropia

$\mathrm{mM} \quad$ Milimolar

35S Promotor do vírus do mosaico da couve-flor

BAP Benzilaminopurina

bO Gene bacteriopsina isolado de Halobacteriu halobium

CTV Virus da tristeza dos citros

CVC Clorose variegada dos Citros

GFP Gene da 'green fluorescent protein'

$\mathrm{GA}_{3} \quad$ Ácido giberélico

$\mathrm{g} \mathrm{L}^{-1} \quad$ Gramas por litro

GUS Gene $\beta$-glucuronidase

HAL2 Gene 3'(2'),5'-bifosfato nucleotidase

kDa $\quad$ Kilo Dalton

manA Gene manA

$\mathrm{mg} \mathrm{L}^{-1} \quad$ Miligramas por litro

MSC Morte súbita dos citros

MT Meio de cultura definido por Murashige \& Tucker (1969)

nptII Gene da neomicina fosfotransferase II

PAL Promotor da fenilalamina amônia-liase

pb Pares de bases

PEG Polietilenoglicol

PCR Reação em cadeia da polimerase

T-DNA Transferred DNA

$\mathrm{Ti} \quad$ Plasmídeo indutor de tumor 


\title{
TRANSFORMAÇÃO GENÉTICA DE CITROS COM OS GENES BACTERIOPSINA (bO), CECROPINA E GUS
}

\author{
Autor: FERNANDO ALVES DE AZEVEDO \\ Orientador: Prof. Dr. FRANCISCO DE ASSIS ALVES MOURÃO FILHO
}

\section{RESUMO}

A utilização de técnicas biotecnológicas como a transformação genética, tem auxiliado os programas de melhoramento de plantas perenes. Essa técnica já é utilizada em citros com sucesso, principalmente para obtenção de plantas tolerantes a doenças. O presente trabalho teve três objetivos: 1.transformação genética do porta-enxerto limão 'Cravo' com o gene bacteriopsina $(b O)$, relacionado com ativação de mecanismos de defesa da planta como morte programada de células e produção de ácido salicílico, com o intuito de aumentar a resistência a gomose de Phytophthora; 2. transformação genética das principais variedades copas de laranja doce ('Hamlin', 'Valência', 'Natal' e 'Pêra') com o gene da cecropina. Esse gene possui atividade antibacteriana, tornando-se possível fonte de resistência a cancro cítrico e clorose variegada dos citros e; 3. avaliar a viabilidade da utilização de um promotor específico de xilema em citros. As transformações foram efetuadas pelo sistema indireto via Agrobacterium tumefaciens, utilizando segmentos juvenis de epicótilo. Testes moleculares foram realizados e confirmaram a inserção dos genes descritos acima. No caso do limão ‘Cravo’ duas plantas foram regeneradas. Na transformação das variedades copa com o gene da cecropina, diferentes taxas de eficiência foram observadas, sendo que melhores resultados foram obtidos para laranja 'Valência (3,3-4,5 \%) e laranja 'Hamlin' (2,5-3,0 \%) em comparação com laranja 'Natal' (1,6-2,0 \%) e laranja 'Pêra' (0,5 \%). 
Plantas de laranja 'Valência' também foram transformadas com o promotor da fenilalamina amônia-liase. Além das transformações, dois bioensaios foram instalados: um com as plantas de limão 'Cravo', visando avaliar resistência a gomose de Phytophthora e outro, com laranja 'Valência' transformada com o gene da cecropina. No primeiro caso, propagaram-se por enxertia plantas transgênicas de limão ‘Cravo’ e, após seis meses fez-se a inoculação com Phytophtora nicotianae, que consistiu na introdução de agulha contaminada com propágulos do patógeno, numa altura de $10 \mathrm{~cm}$ acima da região da enxertia. Vinte e cinco dias após aferiu-se o comprimento e área das lesões, bem como observou-se a presença de goma. Comparando-se o desempenho das duas linhagens transgênicas com o limão 'Cravo' não transformado, uma delas apresentou menor área a lesão. Já para as plantas com o gene cecropina um ensaio com folha destacada foi realizado, em que as mesmas foram perfuradas com auxílio de uma agulha e, posteriormente, pulverizadas com uma suspensão da bactéria Xanthomonas axonopodis pv. citri e, mantidas em tubo de centrífuga (50 mL), onde os pecíolos permaneciam em contato com água estérial ( $2 \mathrm{~mL}$ ). Avaliou-se o período necessário para o aparecimento das primeiras lesões e o tamanho das lesões após quinze dias. Uma planta transgênica apresentou maior resistência perante a testemunha. Nas plantas transformadas com o promotor da fenilalamina amônia-liase, testes para observar a expressão do gene GUS foram realizados e comprovaram a capacidade desse promotor em direcionar os genes para a região dos vasos condutores. Os resultados obtidos nesse trabalho são pioneiros em citros, utilizando os genes $b O$, cecropina e o promotor PAL. 


\title{
GENETIC TRANSFORMATION OF CITRUS WITH BACTERIO-OPSIN (bO), CECROPIN AND GUS GENES
}

\author{
Author: FERNANDO ALVES DE AZEVEDO
}

Adviser: Prof. Dr. FRANCISCO DE ASSIS ALVES MOURÃO FILHO

\section{SUMMARY}

Application of modern biotechnology techniques, as genetic transformation, has helped breeding programs of perennial plant species. This technique is already successfully used in citrus in several countries, mostly to the production of more disease-tolerant plants. Present work had three objectives as it follows: 1. genetic transformation of Rangpur lime rootstock with the bacterio-opsin $(b O)$ gene, related to the activation of plant defense mechanisms such as programmed cell death and salicylic acid production, towards the increase of the tolerance to Phytophthora gummosis; 2. genetic transformation of main sweet orange scion varieties (Hamlin, Valência, Natal and Pêra) with cecropin gene. This gene products present antibacterial activity, becoming a possible source for citrus canker and variegated chlorosis tolerance and. 3 . to test the viability of the use of a xylem-specific promoter (phenylalanine ammonia lyase) in citrus. Transformations were performed by direct system via Agrobacterium tumefaciens, using juvenile citrus epicotyl segments, which showed to be feasible in citrus, once transgenic plants were obtained for all proposed genes. Molecular tests were conduced and confirmed the insertion of the genes described above. In the case of Rangpur lime two plants were regenerated; in the transformation of canopy varieties with cecropin gene, different efficiency rates were observed, and the best results were 
obtained for Valencia sweet orange (3.3-4.5 \%) and Hamlin sweet orange (2.5-3.0 \%), compared to Natal sweet orange (1.6-2.0 \%) and Pêra sweet orange (0.5 \%). Plants of Valência variety were also transformed with the phenylalanine ammonia lyase promoter, resulting in 15 diverse transformation events. Beyond transformations, two bioessays were installed: one with Rangpur lime plants, aiming to evaluate tolerance to gummosis caused by Phytophthora, and another with Valência sweet orange transformed with cecropin gene. In the first case Rangpur lime transgenic plants were propagated through grafting and, after six months, were inoculated with Phytophtora, by introducing a contaminated needle containing the pathogen propagules, at $10 \mathrm{~cm}$ above the grafting region; 25 days later the experiment evaluation was conduced, consisting on measuring the lenght and area of lesions, as well as on the observation of gum. Comparing the performance of Rangpur lime transgenic lines with that of a non-transformed Rangpur lime, one plant presented higher tolerance to gummosis. Although, for the cecropin-gene plants, it was conduced an essay with destached leaves, where these were punched by a needle and then sprayed with a bacterial suspension of Xanthomonas axonopodis pv. citri; they were kept in centrifuge tubes $(50 \mathrm{~mL})$, where petioles mantained contact with sterile water ( $2 \mathrm{~mL}$ ). After 15 days, the necessary period to the first lesions appearance and their size were evaluated. One transgenic plant showed a higher tolerance in comparison to control. In plants transformed with phenylalanine ammonia lyase promoter, tests to observe gus gene expression were performed and comproved its ability to promote and direct gene activity to conductive vessels. This work results are the first in citrus using $b O$ and cecropin genes, and PAL promoter. 


\section{INTRODUÇÃO}

A fruticultura mundial foi responsável pela produção de 497,4 milhões de toneladas em 2004, sendo 21,7\% (108,1 milhões de toneladas) representados pela citricultura, o que faz dos cítricos as frutas mais produzidas no mundo. Nesse contexto, o Brasil se destaca como maior produtor, com aproximadamente 20 milhões de toneladas anuais (2004) e, junto com Estados Unidos, China, Espanha e México, produzem mais de $50 \%$ dos citros consumidos no planeta (FAO, 2005).

O Estado de São Paulo é o principal pólo produtor brasileiro, concentrando-se basicamente em laranjas doces (Citrus sinensis L. Osbeck) das variedades 'Pêra', 'Valência', 'Natal' e 'Hamlin', destinadas à produção de suco concentrado para exportação. O limão ‘Cravo’ (Citrus limonia Osbeck) é o porta-enxerto predominante sendo, ainda o alicerce da citricultura brasileira, que está quase que totalmente apoiada sobre ele.

Apesar da importância do Brasil como produtor mundial de citros, a produtividade desta cultura tem sido muito afetada principalmente por problemas fitossanitários, em combinações que utilizam o limão ‘Cravo' como porta-enxerto. Uma nova doença detectada em pomares localizados nas regiões Sudoeste de Minas Gerais e Norte de São Paulo, denominada morte súbita dos citros (MSC), vem afetando plantas enxertadas sobre limão ‘Cravo’ (Müller \& De Negri, 2001), além das perdas em decorrência do declínio e da gomose de Phytophthora. Com relação às copas, principalmente as laranjas doce têm se apresentado igualmente suscetíveis ao cancro cítrico (Xanthomonas axonopodis pv. citri Vanterin et al.) e à clorose variegada dos citros - CVC (Xylella fastidiosa Wells et al.) e, mais recentemente, ao 'greening', que são doenças causadas 
por bactérias, sendo que as duas primeiras têm sido as grandes responsáveis por perdas significativas na citricultura nos últimos anos.

Dessa maneira, é fundamental manter fontes de variabilidade genética, através da conservação de germoplasma, para permitir a manutenção da base genética das espécies cítricas. Tenta-se garantir, desse modo, que através do melhoramento genético, possam ser solucionados os principais problemas que afetam a agroindústria citrícola (Domingues \& Tulmann Neto, 1998).

Os programas de melhoramento de plantas perenes, como as cítricas, podem durar anos até que se produza uma nova variedade. Assim, a partir da década de 80, uma série de ferramentas biotecnológicas foram desenvolvidas e integradas a programas de melhoramento de citros, destacando-se a hibridação somática, e mais recentemente, a transformação genética.

Técnicas como a transformação genética permitem encurtar o período para se obter uma nova variedade, uma vez que é possível a modificação de características de uma espécie em uma só etapa (Brasileiro \& Dusi, 1999). Em especial, no melhoramento genético convencional dos citros que enfrenta uma série de entraves, como a poliembrionia, a alta heterozigose, a auto e interincompatibilidade e o longo período de juvenilidade, é fundamental a integração dessas técnicas (Grosser \& Gmitter Junior, 1990).

A transformação genética indireta via Agrobacterium, que são bactérias de solo que se associam às plantas causando-lhes tumores, é atualmente o método mais utilizado para transformar dicotiledôneas. Essas bactérias são capazes de transferir seus próprios genes para o genoma vegetal e, a expressão desses genes resulta na síntese de fitohormônios, que levam a formação dos tumores, e de aminoácidos modificados (opinas), substâncias necessárias para a sobrevivência da bactéria. Se os genes responsáveis pela formação de tumores forem removidos, qualquer gene de interesse poderá ser colocado em seu lugar e, através do sistema mediado pela bactéria, ser integrado ao genoma da planta. 
Diversos trabalhos com transformação genética vêm sendo realizados via Agrobacterium tumefaciens, utilizando-se genes que ativam os mecanismos de defesa das plantas, como o da bacteriopsina $(b O)$, caracterizado por ativar a morte programada de células, que foi introduzido em plantas de batata, para se obter resistência a doenças causadas por Phytophthora infestans e Erwinia carotovora (Abad et al., 1997).

Outra estratégia proposta para a obtenção de resistência também contra doenças, no caso bacterianas, seria a expressão de genes de peptídeos com atividade antimicrobiana. Um exemplo é a cecropina, peptídeo lítico encontrado na hemolinfa de insetos que foi introduzido em planta de tabaco (Jaynes et al, 1993). Para doenças vasculares, como a CVC, uma alternativa seria a utilização de promotores que expressam genes em tecidos específicos das plantas. Um exemplo é o promotor da fenilalamina amônia-liase (PAL), caracterizado por expressar genes nos vasos do xilema (Harakawa, 2000). Porém, poucas são as pesquisas realizadas com esses genes em citros. O objetivo deste trabalho foi realizar transformação genética via Agrobacterium tumefaciens, para a introdução do gene $b O$ no porta-enxerto limão 'Cravo', visando resistência a gomose de Phytophthora, bem como o da cecropina nas laranjas 'Hamlin', 'Valência', 'Natal' e 'Pêra', para resistência a cancro cítrico e, do gene gus dirigido pelo promotor PAL em laranja 'Valência', visando expressão específica de gene na região vascular. 


\section{REVISÃO DE LITERATURA}

\subsection{Aspectos gerais do gênero Citrus}

O gênero Citrus pertence à família Rutaceae, que reúne mais dois gêneros com importância econômica: Fortunella e Poncirus. Entre eles, é possível a polinização com obtenção de híbridos, alguns de valor comercial. O número básico de cromossomos é $\mathrm{x}$ $=9$, sendo a diploidia $(2 \mathrm{n}=2 \mathrm{x}=18)$ a condição mais freqüente do gênero Citrus (Moreira \& Pio, 1991).

As plantas cítricas raramente são cultivadas na forma de "pé-franco" e o método de propagação mais usual é a enxertia, ou seja, a união da variedade copa com um portaenxerto mais adaptado a condições adversas, resultando em tolerância a estresses diversos, melhoria da qualidade dos frutos e aumento da produção (Grosser \& Gmitter Junior, 1990). O porta-enxerto predominante na citricultura brasileira, principalmente após a entrada do vírus da tristeza dos citros (CTV) na década de 40, é o limão ‘Cravo', devido às suas características horticulturais muito favoráveis. É altamente tolerante à seca devido ao sistema radicular vigoroso e profundo; ao CTV (Rossetti, 1991), parcialmente tolerante à gomose de Phytophthora (Amorim, 1997), mas suscetível ao declínio (Pompeu Júnior, 2001). Entre os demais porta-enxertos utilizados, citam-se a tangerina 'Cleopatra', o Poncirus trifoliata e o citrumelo 'Swingle' (Salva, 2001). 
Os principais objetivos do melhoramento de citros estão relacionados à resistência a fatores abióticos (baixas temperaturas, alta salinidade, estresse hídrico, etc.) e bióticos (resistência a pragas e doenças). Características horticulturais também são importantes nos programas de melhoramento, tais como: coloração de frutos, menor número de sementes e ampliação do período de safra. Algumas características são influenciadas pelo porta-enxerto, destacando-se o porte da planta, a precocidade da produção, a qualidade dos frutos, a tolerância a estresses e a tolerância ou resistência a doenças (Pompeu Júnior, 1991).

O melhoramento genético convencional do gênero Citrus por hibridação controlada apresenta várias dificuldades que estão ligadas à biologia reprodutiva do gênero, entre elas, a alta heterozigose, a esterilidade de pólen e óvulo, sistemas de incompatibilidade gametofítica, à ocorrência de apomixia facultativa via embrionia nucelar que resulta frequentemente na ocorrência de sementes poliembrionias, e à longa fase juvenil, com período mínimo de cinco anos para o aparecimento das primeiras flores e frutos (Frost \& Soost, 1968). Essas características limitaram o impacto do melhoramento tradicional, por meio de cruzamentos controlados, no lançamento de novas variedades de citros (Grosser \& Gmitter Junior, 1990).

A maioria das espécies cítricas tem uma alta heterozigosidade que produz uma grande segregação dos caracteres genéticos na progênie, reduzindo a possibilidade de restabelecer genótipos com as características desejadas. Finalmente, há uma importante lacuna no conhecimento da genética básica dos citros. É desconhecido como a maioria das características horticulturais importantes são herdadas, e isto torna muito difícil fazer-se um planejamento adequado para escolher o cruzamento mais adequado. Recentemente, o desenvolvimento de marcadores genéticos está proporcionando uma nova ferramenta potencial para a propagação dos citros, mas estes apenas aplicam-se a algumas características de interesse (Navarro et al., 2002).

Com isso o impacto do melhoramento tradicional do gênero Citrus por meio de cruzamentos controlados limitou o lançamento de novas variedades. A maioria das copas e porta-enxertos utilizadas na citricultura foi originada a partir de seleção de 
seedlings obtidos por cruzamentos naturais e por mutantes espontâneos de gemas originados de variedades já existentes (Spiegel-Roy \& Vardi, 1984; Grosser \& Gmitter Junior, 1990; Gmitter Junior et al., 1992). Um exemplo de melhoramento resultante da seleção de clones obtidos via mutações naturais em gemas é a laranja 'Piralima', podendo ser citada, também, a laranja 'Baianinha’, que é possivelmente uma variação da laranja 'Baia', sendo a laranja 'Baia' uma mutação da laranja 'Seleta' (Figueiredo, 1991).

Nos últimos 30 anos, técnicas biotecnológicas têm sido desenvolvidas e aplicadas para sobrepor essas barreiras relacionadas à biologia do gênero Citrus. Dessa maneira, a hibridação somática por fusão de protoplastos tem permitido a transferência de genes entre espécies taxonomicamente iguais ou distantes (Grosser \& Gmitter Junior, 1990). Nos casos em que genes de interesse tenham sido identificados e isolados em espécies não-relacionadas, a transferência pode ser feita por transformação genética (Waara \& Glimelius, 1995).

A cultura dos citros é bastante afetada por inúmeras doenças e, técnicas como a transformação genética, têm auxiliado com sucesso os programas de melhoramento. Os aspectos mais importantes e suas aplicações, relacionados a doenças e transformação genética em citros serão descritos a seguir.

\subsection{Doenças importantes na citricultura brasileira}

Dentre as muitas doenças que afetam a cultura dos citros no Brasil, destacam-se a pinta preta (Guignardia citricarpa Kiely), a verrugose (Elsinoe spp.), a melanose (Diaporthe citri Wolf), a rubelose (Corticium salmonicolor Berk \& BR.), a podridão floral (Colletotrichum acutatum Simmons), causadas por fungos e, nesse grupo, colocase também em destaque, a gomose de Phytophthora (Phytophthora spp.). Entre as doenças bacterianas destacam-se a CVC e o cancro cítrico (Feichtenberger, 2000).

Mais recentemente, duas novas doenças foram detectadas em pomares brasileiros, a primeira em 1999, na região de Comendador Gomes/MG, a morte súbita dos citros, 
ainda de causa desconhecida e, em 2004, foco de 'greening' foi encontrado na região de Araraquara/SP, esta doença tem como agente causal uma bactéria (Fundecitrus, 2005).

Duas viroses têm importância econômica: a tristeza e a leprose (Müller \& Costa, 1991), e uma doença de etiologia desconhecida: o declínio dos citros (Carlos, 1996). A utilização de copas e porta-enxertos resistentes ou tolerantes, de mudas livres de raças severas do vírus e a premunização, vem solucionando os problemas relacionados à tristeza no Brasil (Feichtenberger, 2000).

Dentre as doenças descritas acima as que vêm causando maiores preocupações aos produtores são: 'greening' e MSC devido à recente descoberta; enquanto que cancro cítrico, CVC e a gomose de Phytophthora são as que, realmente, causam perdas significativas todos os anos, preocupando demasiadamente os citricultores brasileiros. Como os genes utilizados neste trabalho estão relacionados a estas doenças, maior abordagem sobre elas é feita na sequência.

\subsubsection{Gomose de Phytophthora}

Entre as principais doenças cítricas estão as causadas pelo gênero Phytophthora, sendo denominado este complexo de 'gomose dos citros'. Esta doença impossibilitou o uso da laranja 'Caipira' como porta-enxerto, que foi substituída pela laranja azeda, altamente resistente à Phytophthora, mas intolerante à tristeza. Assim, foi substituída

pelo limão 'Cravo' que apresenta menor resistência a esta doença (Feichtenberger, 1998).

A gomose dos citros é causada por patógenos do gênero Phytophthora, que são endêmicos no solo de pomares na maioria das áreas citrícolas do mundo (Erwin \& Ribeiro, 1996). Pode-se afirmar que, na citricultura mundial, o gênero Phytophthora causa a mais séria doença de solo da cultura, sendo amplamente distribuído em todas as regiões produtoras, causando perdas na produção desde regiões áridas até as tropicais (Whiteside et al., 1996). 
No Brasil, P. nicotianae Breda de Haan (P. parasitica Dastur) e P. citrophthora (Sm. \& Sm.) Leonian são as espécies mais freqüentes. No Estado de São Paulo, $P$. nicotianae está associada às perdas mais significativas provocadas por estes patógenos, e tem sido a principal responsável pela doença, sendo encontrada em mais de 95\% dos pomares e viveiros contaminados naquele Estado (Feichtenberger, 2000; Medina Filho et al., 2004).

Os principais sintomas da gomose no campo são morte de tecidos internos da casca e do lenho na região do tronco da planta; formação de calo nas bordas das lesões; exsudação de goma; seca e fendilhamento da casca; podridão do colo da planta, raízes e radicelas; amarelecimento uniforme e progressivo de folhas; baixo desenvolvimento de folhas novas, murcha e queda de folhas da planta (Timmer et al., 2000). Lesões em estágio avançado podem levar a planta à morte, uma vez que há um rápido declínio, devido à destruição do floema, restringindo o fluxo de seiva da copa para o sistema radicular (Rosseti, 1947).

As principais estratégias de controle são o plantio de mudas sadias; evitar áreas infestadas com o patógeno e com excesso de umidade do solo; controle cultural evitando ferimentos nas plantas, e o uso de controle químico com produtos sistêmicos. A busca por variedades resistentes a pragas e doenças é sempre uma medida importante (Widmer et al., 1998) e, no caso das doenças causadas por Phytophthora spp. o uso de porta-enxertos resistentes, com características horticulturais desejáveis, constitui-se na principal estratégia de manejo (Broadbent, 1997; Siviero et al., 2002).

Entre os porta-enxertos, Poncirus trifoliata, citrumelo 'Swingle', citranges e laranja azeda são altamente tolerantes à Phytophthora. As tangerinas, tangelos e limões são medianamente tolerantes, enquanto que as laranjas doces, incluindo a laranja ‘Caipira’, são altamente suscetíveis à doença (Amorim, 1997). 


\subsubsection{Clorose variegada dos citros e cancro cítrico}

Inúmeras doenças vêm afetando a citricultura mundial e, dentre as causadas por bactérias, duas são extremamente graves no Brasil: o cancro cítrico (Xanthomonas axonopodis pv. citri) (Fundecitrus, 1997) e a CVC (X. fastidiosa) (Rossetti, 1991) que estão sendo responsáveis, indiretamente, pela diminuição do parque citrícola brasileiro. No Estado de São Paulo houve uma redução de 10\% da área comercial citrícola nos últimos cinco anos, em vista a essas doenças e outras como a MSC, que têm sido um dos principais limitantes da expansão dessa área (Cepea, 2005).

O cancro cítrico, doença bastante conhecida pelo citricultor brasileiro, foi constatado no Brasil em 1957, na região de Presidente Prudente/SP (Fundecitrus, 1997). Já a clorose variegada dos citros (CVC) surgiu mais tarde em 1987, no norte do Estado de São Paulo e as plantas afetadas pela doença apresentam frutos de tamanho reduzido, endurecidos, sendo impróprios para comercialização, devido ao entupimento dos vasos do xilema, pela bactéria causadora da doença (Feichtenberg, 2000). Um agravante é que as laranjas 'Hamlin', 'Valência', 'Pêra' e 'Natal', principais copas cultivadas no país, são igualmente atacadas por essas doenças, independentemente do porta-enxerto utilizado.

A bactéria do cancro cítrico é de fácil disseminação no ambiente, e um de seus vetores é o homem pelo transporte de ferramentas e utensílios contaminados. Folhas, ramos e frutos jovens são preferidos pela bactéria, pois lhe é facilitada a penetração por aberturas naturais. Com medidas de exclusão e erradicação conseguiu-se manter a doença sob relativo controle até meados de 1996, quando se presenciou pela primeira vez, nos pomares brasileiros, a larva minadora dos citros (Phylocnistis citrela Stainton) que vem contribuindo para aumentos significativos da doença, por facilitar a entrada da bactéria, através da abertura de galerias nas folhas, após isso, houve um crescimento surpreendente do número de focos da doença. Essa praga provoca ferimentos nas folhas e outros órgãos da planta, favorecendo a penetração da bactéria (Gravena, 1998; Bergamin-Filho et al., 2000). 
O cancro cítrico é uma doença causada pela bactéria $X$. axonopodis pv. citri. Seus sintomas são lesões, pústulas ou cancros sobre as folhas, ramos e frutos. Quando o ataque é severo ocorrem desfolha e queda de frutos (Zubrzycki, 1998). Não existe um controle químico eficiente, portanto medidas preventivas são recomendadas, como mudas fiscalizadas, desinfecção de materiais de colheita e dos veículos que entram nos pomares, plantio de quebra-vento e o controle da larva minadora dos citros. Com a entrada da bactéria na área, torna-se necessário fazer-se a erradicação do foco e plantas adjacentes, o que está previsto em lei federal (Fundecitrus, 1997).

A clorose variegada dos citros, outra doença bacteriana importante da cultura, foi relatada pela primeira vez em 1987 em pomares da região noroeste do Estado de São Paulo (Pompeu Júnior et al., 1998). Causada pela bactéria Xylella fastidiosa, tem como característica a colonização e posterior entupimento dos vasos do xilema. A CVC afeta indistintamente as principais copas cultivadas na citricultura brasileira (Coletta Filho \& Machado, 2002).

Plantas doentes apresentam um aspecto de debilidade geral, mostram-se pequenas manchas internervais amarelas na face superior das folhas e nos ramos é comum o encurtameto dos entrenós. Observa-se uma tendência à frutificação em 'pencas' e, os frutos se tornam duros, pequenos e adquirem uma coloração típica de fruto maduro (Palazzo \& Carvalho, 1992).

A bactéria causadora da CVC, é transmitida e disseminada nos pomares por insetos vetores comumente denominados por cigarrinhas das famílias Cicadellidae e Cercopidae. Os insetos membros destas famílias apresentam em comum a característica de usar a seiva do xilema de plantas como fonte de alimento (Donadio \& Moreira, 1998).

A CVC tornou-se uma das principais doenças da citricultura brasileira. Além dos prejuízos que causa, trouxe a necessidade de reestruturação das técnicas de produção de mudas, a obrigatoriedade do monitoramento dos vetores da doença (cigarrinhas) nas regiões mais afetadas, além da utilização de podas de ramos com sintomas e da busca de 
variedades resistentes, que se tornaram as principais táticas de controle (Laranjeira, 1997).

O desenvolvimento de variedades cítricas agronomicamente aceitáveis com adequado nível de resistência a doenças, é ainda a forma mais econômica e eficiente de controlar doenças como o cancro cítrico e a CVC (Coletta-Filho \& Machado, 2002), uma vez que o controle químico de doenças bacterianas, com a utilização de antibióticos, como estreptomicina ou tetraciclina, é inviável economicamente.

\subsection{Transformação genética}

\subsubsection{Aspectos Gerais}

Pesquisas relacionadas ao melhoramento genético tem levado a aumentos consideráveis na produtividade de diversas espécies cultivadas através de diversas abordagens metodológicas para a obtenção de maior ganho genético após seleção. A busca por genes visando resistência a patógenos no germoplasma silvestre, seja dentro da espécie ou em plantas aparentadas, beneficiou muitas culturas.

Por outro lado, a tecnologia do DNA recombinante possibilitou o isolamento de genes e a inserção estável em um genoma hospedeiro (Quecini \& Vieira, 2001). Esta técnica, também chamada de transformação genética, pode ser definida como a introdução controlada de ácidos nucléicos em um genoma receptor, excluindo-se a introdução por fecundação. Trata-se da transferência não sexuada de genes para plantas, assim como a hibridação somática e cibridação. É um processo controlado, onde apenas um fragmento definido de ácido nucléico (DNA) é introduzido no genoma do hospedeiro, ou genoma receptor, devendo ser a ele integrado (Brasileiro \& Dusi, 1999). A inserção estável dessas moléculas em um genoma hospedeiro dá origem a um indivíduo geneticamente igual ao receptor da molécula DNA recombinante, porém acrescido de uma característica nova e particular (Quecini \& Vieira, 2001). 
Existem diversas técnicas de transformação genética de plantas, agrupadas em duas categorias: transferência indireta e direta de genes. A indireta é aquela em que o DNA exógeno é inserido no genoma pela ação de um vetor biológico, enquanto que a direta é baseada em processos físico-bioquímicos. A transformação indireta baseia-se principalmente no sistema mediado por bactérias do gênero Agrobacterium e, tem sido o método mais utilizado para obtenção de plantas transgênicas. Agrobacterium tumefaciens e A. rhizogenes são bactérias fitopatogênicas de solo, pertencentes a família Rhizobiaceae, que causam doenças em dicotiledôneas, conhecidas como galhas da coroa e raiz em cabeleira, respectivamente. Ambas são economicamente importantes, especialmente em plantas perenes em regiões de clima temperado (Brasileiro \& Dusi, 1999).

Fernandes \& Martin (1985) observaram que tecidos da galha da coroa, quando retirados da planta e cultivados in vitro, apresentavam a capacidade de se proliferar indefinidamente em meio de cultura, sem o acréscimo de reguladores de crescimento. Foi então notado que a aparição da galha era, na realidade, o resultado de um processo natural de transferência de genes entre a agrobactéria e a célula vegetal.

A indução do tumor é provocada pela presença de um grande plasmídeo denominado Ti (tumour-inducing), o qual é encontrado em linhagens virulentas de $A$. tumefaciens (Turgeon, 1982). Esse plasmídeo possui um fragmento de DNA bacteriano, chamado T-DNA, que durante a infecção é transferido para as células e inserido no genoma da planta. O T-DNA contém genes envolvidos na biossíntese constitutiva de fitohormônios (auxinas e citocininas) que alteram o programa de desenvolvimento normal do tecido infectado, ocasionando a formação do tumor. Além disso, contém também genes (oncogenes) para a síntese de açúcares e aminoácidos denominados de opinas, que são responsáveis pela sobrevivência da bactéria, que os utilizam como fonte de carbono/nitrogênio (Oger et al., 1997).

Extremidades repetidas de 25 pares de base (pb) nas bordas direita (RB - Right border) e esquerda (LB - left border) delimitam o T-DNA e são necessárias para a transferência do mesmo (Wang et al., 1984). Compostos fenólicos liberados pelos 
tecidos vegetais lesionados, ativam regiões específicas (vir), iniciando o processo de transferência do T-DNA para a célula vegetal (Stachel et al., 1985). A Agrobacterium possui também genes cromossomais (chv) que garantem a ligação entre as células bacterianas e hospedeira, permitindo a formação do poro de passagem do complexo contendo a fita - T (Sheng \& Citovsky, 1996).

A região de virulência, denominada região vir é responsável pelo processo de transferência, sendo que o processo de indução e transferência da fita - T é controlado pela expressão coordenada dessa região. O locus virA codifica uma proteína de membrana que percebe a presença de metabólitos da planta injuriada (acetoseringona). Ao se ligar à acetoseringona, a proteína VirA “ativada” modifica a proteína VirG, que também é expressa constitutivamente, mas em menor escala através da fosforilação da mesma. A proteína VirG fosforilada é a responsável pela indução da transcrição de toda região vir. Para formar a fita - T, o operon virD codifica endonucleases capazes de reconhecer e clivar dentro dos 25 pares de base que delimitam a região-T. A transferência da fita - $\mathrm{T}$ é polar, sempre da direita para a esquerda. A fita - $\mathrm{T}$ é transferida para a célula vegetal na forma fita simples, protegida na porção 5’ da molécula pela proteína VirD2 e, ao longo da fita - T, pela proteína VirE2 (Zambryski, 1992).

O T-DNA liberado é protegido, por ligações ao longo da fita simples, pela proteína VirE2, que também seria responsável pela organização estrutural da fita durante o trajeto entre a célula bacteriana e a célula vegetal. Proteínas codificadas pelos locus virB garantiriam a passagem pela membrana da bactéria, pela formação de poro de passagem entre a membrana e parede celular (Zambryski, 1992).

O processo de transferência pode ser dividido em duas etapas principais: uma etapa bacteriana e uma etapa eucariótica que ocorre na célula vegetal (Zupan \& Zambryski, 1995). A etapa bacteriana inclui a produção e exportação de um vetor funcional contendo a informação genética do T-DNA (Tinland, 1996). A etapa eucariótica inclui o reconhecimento entre a Agrobacterium e a célula hospedeira, a transdução de sinais vegetais de patogênese e a ativação dos genes vir (Sheng \& 
Citovsky, 1996). Uma vez que o segmento a ser transferido é definido por suas bordas, a região codante do T-DNA do tipo selvagem pode ser substituída por qualquer outra sequência de DNA sem que sua transferência da Agrobacterium para a planta seja prejudicada. A substituição dos oncogenes por genes de interesse, flanqueados pelas bordas do T-DNA, fornece um sistema eficiente de obtenção de plantas transgênicas (Brasileiro \& Dusi, 1999). A integração Agrobacterium-célula vegetal é o único caso de transferência de genes entre reinos diferentes, tendo sido descrita como um exemplo de engenharia genética da natureza (Tempé \& Schell, 1977).

A produção de transgênicos tem sido amplamente realizada com a utilização de marcadores seletivos codificando para resistência a antibióticos. A União Européia proibiu a comercialização de alimentos transgênicos com genes de resistência a antibóticos, até 2005 (Navarro et al., 2002), estimulando assim o desenvolvimento de sistemas alternativos de seleção, como os baseados no uso de agentes nãometabolizáveis que empregam por exemplo o gene manA (Boscariol et al., 2003).

Diante disto, considera-se contrapositivo sacrificar os profícuos programas de melhoramento em favor da biotecnologia, que deve ser considerada como uma ferramenta de auxílio ao melhoramento. É evidente que as contribuições desta ferramenta na agricultura já se fazem sentir em vários países cujas variedades transgênicas vêm ocupando grandes áreas de plantio com diferentes espécies. Entretanto, as plantas transgênicas serão apenas parte da contribuição que a biotecnologia promete dar ao melhoramento de plantas, pois somente a utilização correta da biotecnologia, como auxiliar ao melhoramento, permitirá que os riscos sejam minimizados e os benefícios maximizados (Borém \& Milach, 1999).

A maioria dos países que desenvolvem pesquisas com organismos geneticamente modificados, dentre eles o Brasil, tem uma legislação própria de biossegurança. A legislação brasileira levou à criação da Comissão Técnica Nacional de Biossegurança CTNBio, composta por representantes do Poder Executivo, da comunidade científica, do setor empresarial que atua em biotecnologia, de representantes dos órgãos de defesa do consumidor e de órgãos legalmente constituídos de proteção à saúde do trabalhador. 
Essa Comissão é responsável pela regulamentação da biossegurança no País, no que se refere ao uso e liberação de organismos geneticamente modificados, desde o laboratório até o meio ambiente (Quencini \& Vieira, 2001). Nova Lei de Biossegurança foi aprovada pela Câmara dos Deputados no último dia 2 de março, colocando fim a dois anos de discussões. Essa lei trata dos estudos científicos envolvendo células-tronco embrionárias e o plantio de sementes transgênicas no país (CTNBIO, 2005)

\subsubsection{Transformação genética em citros}

As principais instituições envolvidas na obtenção de plantas transgênicas de citros estão localizadas nos Estados Unidos, mais precisamente na Universidade da Flórida, liderados pelos pesquisadores Dr. Jude Grosser, Dra. Glória Moore e Dr. Dean Gabriel, que trabalham com hibridação somática e transformação genética utilizando calos embriogênicos ou segmentos internodais e de epicótilo e, na Espanha, no Instituto Valenciano de Investigações Agrárias (IVIA), coordenado pelos pesquisadores Dr. Leandro Peña e Dr. Luis Navarro (Leite et al., 2002) que utilizam principalmente segmentos juvenis de epicótilo e mais recentemente, segmentos internodais maduros.

No Brasil, trabalhos de transformação genética de citros têm sido desenvolvidos principalmente com laranja doce (C. sinensis), no Instituto Agronômico do Paraná (Bespalhok et al., 2001), no Centro de Energia Nuclear na Agricultura e na Escola Superior de Agricultura Luiz de Queiroz, ambos da USP (Mendes et al., 2002; Almeida et al., 2003) e no Centro APTA - Citros 'Sylvio Moreira' do Instituto Agronômico de Campinas (Dezotti et al., 2004).

A primeira transformação genética de citros foi realizada pela técnica de absorção direta de DNA em protoplastos, de células de laranja doce (Citrus sinensis L. Osbeck), por meio de polietileno glicol (PEG). Entretanto, a regeneração de plantas não foi constatada (Kobayashi \& Uchimya, 1989). Mesma técnica foi utilizada por Vardi et al. (1990) para transformar o limão Rugoso (C. jambhiri Lush.) e por Fleming et al. (2000), em laranja doce 'Itaboraí' (C. sinensis). Por eletroporação de protoplastos, Hidaka \& 
Omura (1993) transformaram tangerina 'Ponkan' (C. reticulata Blanco), enquanto que Yao et al. (1996) fizeram bombardeamento de partículas em células embriogênicas de tangelo (C. reticulata Blanco x C. paradisi Macf.).

Outras transformações têm sido realizadas com sucesso, via Agrobacterium cocultivadas com segmento internodal de plantas in vitro, como de laranja 'Pineapple' ( $C$. sinensis L. Osbeck), realizada na Espanha, que abriu a possibilidade de transferir genes de importância agronômica para as laranjas doces (Peña et al., 1995).

Porém, a eficiência de transformação obtida em segmentos internodais ainda é baixa. Em citrange 'Carrizo’ foi de 2\% (Moore et al., 1992), em laranja doce 7,9\% (Peña et al., 1995) e em lima Mexicana de 6,7\% (Peña et al., 1997). Na tentativa de aumentar a eficiência de transformação, vários trabalhos vêm sendo realizados utilizando diferentes tipos de explantes como: segmento internodal (Pérez-Molphe-Balch \& Ochoa-Alejo, 1998), células em suspensão (Hidaka et al., 1990), protoplastos (Fleming et al., 2000) e segmentos de epicótilo (Moore et al., 1992; Peña et al., 1997; Cervera et al., 1998; Mendes et al., 2002).

A utilização de genes de interesse agronômico na transformação genética de citros, já tem sido realizada, embora, ainda existam poucos genes disponíveis para essa finalidade. Dentre estes se destacam os trabalhos que utilizam o gene que codifica a capa protéica do vírus da tristeza que foi introduzido em laranja azeda (Citrus aurantium L.), lima ácida Key [C. aurantiifolia (Christm.) Swingle] (Gutiérrez-E et al., 1997), em lima ácida Mexicana (C. aurantiifolia) (Domíngues et al., 2000) e em pomelo (C. paradisi Macfad.) (Febres et al., 2003).

Uma limitação para o cultivo de citros em algumas regiões do mundo tem sido a alta sensibilidade das plantas cítricas a solos salinos. Ensaios realizados na Espanha, com transformação via Agrobacterium tumefaciens, levaram à introdução do gene HAL2, em citrange 'Carrizo'. Esse gene, originalmente isolado de leveduras, confere resistência à salinidade (Cervera et al., 2000). 
Os genes $L E A F Y$ e APETALA1, que promovem a iniciação floral, também foram introduzidos em citrange 'Carrizo' e ambos conferiram aceleração do florescimento, reduzindo de forma sensível, a fase juvenil das plantas, que floresceram logo no primeiro ano (Peña et al., 2001).

A resistência a baixas temperaturas é outra característica desejável em plantas do gênero Citrus. Alguns trabalhos foram efetuados com esse objetivo, como a introdução do gene CS-ACS1, via Agrobacterium tumefaciens, em diversas espécies cítricas. Esse gene confere resistência a baixas temperaturas e foi o primeiro relato do controle da biossíntese de etileno em citros através da engenharia genética (Wong et al., 2001).

Fagoaga et al. (2001) introduziram o gene $P R-5$ do tomateiro, que sintetiza uma proteína relacionada à patogenicidade, em laranja doce, e obtiveram redução significativa no desenvolvimento de lesões causadas por Phytophthora citrophthora. Este vem a ser até o momento, o único trabalho visando tolerância a patógenos desse gênero.

Resultados mais recentes foram obtidos por Boscariol (2004) que transformou as principais variedades copa de laranja doce cultivados no Brasil, com os genes atacina ( $a t t A)$ e Xa21, visando resistência a doenças bacterinas, como o cancro cítrico e a CVC. Testes preliminares, utilizando folhas destacadas, mostraram resultados promissores quanto à resistência dos materiais transformados diante à Xanthomonas axonopodis pv. citri.

\subsection{Transformação genética visando resistência a doenças}

Fitopatologistas e melhoristas reconhecem que o melhor método de controle de doenças de plantas é o desenvolvimento de variedades resistentes a doenças, sendo este um dos principais objetivos dos programas de melhoramento.

A produção de plantas transgênicas resistentes a doenças tem sido feita utilizando-se diversas estratégias, introduzindo genes que estimulam o sistema de defesa 
da planta (PAP e $b O)$ bem como genes de origem não vegetal que codificam proteínas antibacterianas (atacina e cecropina) além disso, a utilização de promotores que expressam genes em tecidos específicos das plantas também vêm sendo sugerida.

\subsubsection{Genes que estimulam o sistema de defesa das plantas}

A determinação dos mecanismos de proteção desenvolvidos pelas plantas é essencial para a obtenção de variedades mais resistentes. As plantas podem ter resistência local, também conhecida como resposta de hipersensibilidade (HR), onde há morte de células situadas nos locais por onde o patógeno entra; com isso, a planta impede o acesso do patógeno a células vizinhas, limitando a infecção (Mittler \& Rizhsky, 2000). Acúmulos de ácido salicílico (AS) e proteínas relacionados com a patogenicidade, funcionam como indutores dos processos de morte programada de células que resultam na formação de zonas de células mortas ao redor do local de infecção, chamado de lesão de resposta hipersensitiva (Rizhsky \& Mittler, 2001).

A resposta de hipersensibilidade (HR) é uma manifestação comum de resistência de plantas a doenças, que é caracterizada pela rápida morte de células ao redor do ponto de infecção, restringido o sistema de ataque do patógeno (Yalpani et al., 1991). Nas plantas superiores a morte programada de células pode ser ativada durante a resposta de hipersensibilidade a certos patógenos e está relacionado a diversos processos, como a produção de ácido salicílico e de proteínas relacionadas com a patogenicidade (Mittler et al., 1995).

Alguns autores têm proposto a introdução de genes cujos produtos imitam o fenótipo da HR em plantas. Seriam lesões semelhantes às de hipersensibilidade apresentadas pela presença do patógeno, denominadas disease lesion mimic. Para isso, genes vêm sendo selecionados e incorporados às plantas com o intuito de se obter resistência a fungos, bactérias e vírus causadores de doenças. Um exemplo é o gene bacteriopsina (bO), que codifica a proteína bacteriopsina, e foi isolado de Halobacterium 
halobium. Esta proteína está relacionada ao fluxo de prótons pela membrana plasmática (Krebs \& Khorana, 1993).

A expressão desse gene está relacionada com mecanismos de defesa das plantas pela ativação da morte programada de células em plantas superiores, induzindo fenótipos que imitam lesões de hipersensibilidade, e na ausência do patógeno mostra elevada expressão de genes relacionados com HR, incluindo quitinase, glucanase, compostos antivirais e ácido salicílico (Mittler et al., 1995). Esses genes vêm indicando em plantas de tabaco, proteção contra doenças e, em plantas de batata, aumentou a tolerância para alguns isolados de Phytophthora infestans, sendo que as plantas transgênicas exibiram fenótipos que imitavam lesões, incrementando os níveis de ácido salicílico, resultando em ativação das defesas das plantas (Abad et al., 1997).

Plantas de tabaco expressando o gene $b O$ apresentaram fenótipo muito similar ao de lesões causadas pela hipersensibilidade, na ausência de patógenos, o que mostra elevada expressão de genes relacionados com mecanismos de defesa. As plantas transgênicas apresentaram proteção contra o vírus do mosaico do tabaco (TMV) e a Pseudomonas syringae pv. syringae (Mittler et al., 1995). A introdução do mesmo gene, agora em tomateiro, resultou no aumento da tolerância à $P$. syringae pv. tomato (Rizhsky \& Mittler, 2001).

Em batata, plantas transgênicas com gene $b O$, que apresentavam um fenótipo que imitavam lesões (lesion mimic), foi possível detectar um aumento da tolerância para alguns isolados de $P$. infestans. Incrementos dos níveis de ácido salicílico e super expressão de RNAm de proteínas relacionadas com a patogenicidade, também foram observados, que são evidências do desenvolvimento de resistência sistêmica adquirida, resultando na ativação dos mecanismos de defesa das plantas (Abad et al., 1997).

A integração estável do gene $b O$, também foi confirmada em Catharanthus roseus, uma planta herbácea que está sendo utilizada como modelo em experimentos de interação planta-patógeno por ser hospedeira de Xylella fastidiosa, bactéria responsável pela clorose variegada do citros (CVC) (Guidetti-Gonzalez et al., 2001). 
Outro gene relacionado à ativação dos mecanismos de defesa das plantas é a proteína antiviral denominada 'Pokeweed Antiviral Protein' (PAP) isolado de Phytolacca americana. Esse gene codifica proteínas que inativam ribossomos, com potente ativação antiviral e a expressão constitutiva deste gene em tabaco, estimulou a expressão de PR-proteínas (Zoubenko et al., 1997).

O gene PAP tem potencial antiviral contra muitas viroses vegetais e animais, incluindo o HIV (Timmer et al., 1997). Plantas de batata transformadas com este gene apresentaram-se resistentes ao vírus X da batata (PVX), além de atrasar o aparecimento de sintomas e a mortalidade de plantas causadas por Rhizoctonia solani (Zoubenko et al., 2000).

Lesões de hipersensibilidade são expressões constitutivas de genes que ativam o sistema de defesa das plantas, porém esse fenótipo pode acarretar efeitos adversos, perturbando o desenvolvimento das plantas (Rizhsky \& Mittler, 2001). A seleção de plantas com baixa expressão do gene seria uma maneira de contornar esse problema, resultando na produção de poucas lesões, mas que influenciasse a resistência das plantas aos patógenos (Mitler et al., 1995). Outra forma seria a utilização de promotores induzíveis, regulando a expressão dos genes apenas no momento e local da infecção, evitando a ativação espontânea de mecanismos de defesa (Rizhsky \& Mittler, 2001).

\subsubsection{Peptídeos antimicrobianos}

Os genes utilizados em ensaios de transformação são obtidos dos mais diversos organismos superiores, que possuem sistemas de proteção contra infeções a microorganismos. Os insetos, por exemplo, possuem um eficiente sistema de defesa contra bactérias e outros parasitas, que foi bastante estudado em Hyalophora cecropia, derivando na produção de peptídeos com potente atividade antibacteriana, tais como as cecropinas, que pertencem a uma família de pequenos peptídeos, isolados da hemolinfa de insetos, que exibem atividade lítica e antibactericida contra muitas bactérias gram- 
positivas e gram-negativas (Boman \& Hultmark, 1987). São descritos mais de 500 tipos de peptídios com essa característica, procedentes de uma grande variedade de organismos: bactérias, fungos, insetos, plantas, vertebrados, etc (Zasloff, 2002). Os peptídeos antibacterianos formam uma nova classe de compostos e tem recebido muita atenção na área médica, devido ao potencial uso como complemento aos tradicionais antibióticos (Hancock \& Lehrer, 1998).

Estruturalmente, esses peptídeos têm uma região N-terminal básica e uma longa sequência hidrofóbica na região C-terminal. Essas características são necessárias para a ação antibacteriana das cecropinas através da formação de canais nas membranas, provocando o vazamento de componentes celulares e, consequentemente, a morte da bactéria (Christensen et al., 1988). A aplicação deste mecanismo seria uma importante estratégia para a obtenção de resistência contra doenças bacterianas.

Vários trabalhos de transformação genética de espécies vegetais com peptídeos antibacterianos foram publicados nos últimos anos. Batata e fumo foram as espécies mais utilizadas, principalmente pela facilidade da cultura de tecidos e a importância das bacterioses. Montanelli \& Nascari (1991) transformaram batata com um gene responsável pela produção de cecropina e encontraram resultados positivos contra Ralstonia solanacearum em testes preliminares in vitro com extratos de plantas transgênicas.

A cecropina é um peptídeo lítico (Jaynes et al., 1993) que foi isolado pela primeira vez da hemolinfa de H. cecropia (Steiner et al., 1981). Sendo que mais recentemente, descreve-se a existência de vários tipos de cecropinas: A, B e D. Diferentes estudos demonstram que baixas concentrações desses peptídeos apresentam atividade antibacteriana contra um grande número de bactérias (Sharma et al, 2000), tornando as cecropinas bons candidatos para melhorar a resistência de plantas contra microorganismos, mediante técnicas de transformação genética.

Jaynes et al. (1993), utilizando o gene Shiva-1, um análogo sintético da cecropina, obtiveram alta expressão em plantas transgênicas de fumo que mostravam um aumento de resistência a $R$. solanacearum. Estudos realizados visando observar o crescimento de 
$X$. fastidiosa in vitro, utilizando meio de cultura baseado no fluido do xilema de videiras, acrescido de cecropina sintética, demonstram que esses peptídeos são bastante potentes contra esta bactéria (Andersen et al., 2004).

Estudos in vitro com o peptídeo sarcotoxina (grupo das cecropinas), que foi isolado de larvas de Sarcophaga peregrina, realizado por pesquisadores japoneses, mostraram alta eficiência na inibição do crescimento de algumas bactérias causadoras de doenças em plantas, especialmente para X. axonopodis pv. citri (Ohshima et al., 1999). No Brasil, Bespalhok et al. (2001) transformaram laranja 'Pêra' com o gene da sarcotoxina e observaram maior tolerância à bactéria do cancro cítrico nas plantas que estavam expressando o gene introduzido.

Plantas transgênicas também têm sido desenvolvidas para expressar peptídeos antimicrobianos de plantas (alfa-tionin e proteínas de lipídeos transfer) e de origem não vegetal (lactoferin humano). Plantas de tabaco foram transformadas para expressar o gene alfa-tionin de cevada e, mostraram redução das necroses nas folhas quando inoculadas com suspensões de P. syringae pv. syringae (Carmona et al., 1993).

A atacina é outro peptídeo isolado de insetos, que vem sendo utilizado para o desenvolvimento de plantas transgênicas. Em alguns experimentos, plantas transgênicas de maçãs tendo o gene Atacina E mostraram redução de sintomas do fogo bacteriano de 56 para 5\% (Norelli et al., 1994).

Recentemente Boscariol (2004) transformou as principais variedades copa de laranja doce, cultivadas no Brasil, com o gene da atacina, visando resistência a doenças bacterianas. Testes preliminares em plantas de laranja 'Hamlin' transgênicas demonstraram aumento da resistência à Xanthomonas axonopodis pv. citri, bactéria causadora do cancro cítrico.

\subsubsection{Expressão de genes no xilema}

O maior desafio na obtenção de plantas transgênicas resistentes a doenças vasculares como a CVC e o 'greening', está na localização dos patógenos na planta, o 
que requerem construções que acumulem a expressão de proteínas nesses tecidos da planta (Harakava, 2000).

Poucas proteínas são encontradas nos vasos do xilema e a produção de algumas está localizada nas raízes, região rica em tecidos vasculares (Sakuta et al., 1998). A identificação e localização específica destas proteínas torna seu uso apropriado como genes promotores para dirigirem, por exemplo, peptídeos para os vasos do xilema, visando tolerância a doenças como a CVC (Harakava, 2000).

Genes que codificam enzimas envolvidas no metabolismo de fenilpropanóides e síntese de precursores de lignina como as fenilalamina amônia-liase (PAL) (Zhu et al., 1995) têm sido caracterizados em um número grande de espécies e usualmente compreendem famílias de 2 a 6 membros. Famílias do gene PAL em Arabidopsis thaliana têm 3 membros, PAL1, PAL2 e PAL3 (Wanner et al., 1995).

A existência de múltiplas isoformas de $P A L$ em plantas confere flexibilidade na expressão destas enzimas, o que tem sido demonstrado usando promotores PAL1, PAL2 e PAL3 de feijão francês, com gus e introduzido em plantas de tabaco, batata, e Arabidopsis thaliana (Shufflebottom et al., 1993). O promotor PAL2 com gus mostrou expressão específica no xilema, enquanto que expressão gus mediada pelo PAL3 foi detectado apenas em células isoladas circundando o sistema vascular.

Harakava (2000) clonou o gene promotor PAL de laranja doce (PALCs) e transformou tabaco, via Agrobacterium, com uma construção contendo o gene repórter gus sob o controle deste promotor e, demonstrou que o mesmo confere expressão do gene, preferencialmente, mas não exclusivamente, nos tecidos do xilema

A expressão do gene $P A L$ pode ser induzida por fatores bióticos e abióticos, incluindo ferimentos, luz ultra-violeta, infecções por patógenos, exposição a sais de metais pesados (Smith et al., 2001). Gray-Mitsumune et al. (1999) transformaram Arabidopsis thaliana e tabaco com o gene gus utilizando o promotor PAL e análises histoquímicas da atividade Gus nos transformantes primários mostraram que a atividade foi consistentemente localizada no sistema vascular de ramos, folhas, raízes e flores. 
A utilização de genes repórteres como a enzima beta glucoronidase tem sido também realizada com sucesso para examinar a expressão do gene $P A L$ em planta de tabaco (Huang \& McBeath, 1994), A. thaliana (Giacomin \& Szaly, 1996) e feijão (Bevan et al., 1989). Porém, esse método é destrutivo, assim outros estudos vêm utilizando o gene repórter $g f p$, que pode ser visualizado facilmente em tecidos vivos, usando microscopia fluorescente convencional. Este método foi utilizado com sucesso por Rookies \& Cahill (2003) em A. thaliana.

\subsection{Considerações Finais}

Os citros ocupam uma posição de destaque entre as frutíferas, seguidos pelas culturas da banana, uva e maçã, por isso a demanda por pesquisas visando melhoria da cultura é crescente, seja no aspecto fitossanitário ou de qualidade da fruta produzida. Apesar da liderança brasileira na produção mundial de citros, a produtividade desta cultura tem sido muito afetada principalmente por problemas fitossanitários, que vêm contribuindo para reduções de safras nos anos recentes.

Objetivando-se melhorar a produtividade e minimizar os problemas fitossanitários nos pomares, que vêm causando diminuição da área de pomares em produção e a desaceleração do rítmo de novos plantios, tem-se optado pelo melhoramento genético através de técnicas biotecnológicas, uma vez que os pesquisadores têm encontrado dificuldades para desenvolver programas de melhoramento convencional devido a aspectos da biologia reprodutiva do gênero Citrus.

Ainda que as técnicas convencionais sejam indispensáveis, fica evidente que novos procedimentos, como a transformação genética, necessitam ser incorporados como complemento para que os avanços ocorram mais rapidamente, razão pela qual se tem concentrado esforços na aplicação de técnicas alternativas no melhoramento genético dos citros. 
Atualmente, o Brasil possui ensaios em laboratório e casa de vegetação com plantas cítricas transgênicas. No entanto, o plantio comercial ainda não foi autorizado. Dispor de variedades modificadas geneticamente, pode vir a ser uma alternativa promissora aos citricultores, pois essas poderão apresentar ganhos imediatos em termos de produtividade, fitossanidade e/ou qualidade da fruta. Por isso, a adequada solução às questões de biossegurança torna-se urgente, cabendo às instituições de pesquisa e empresas envolvidas no assunto, minimizar os riscos da utilização dos mesmos, quando eles existirem. 


\section{MATERIAL E MÉTODOS}

\subsection{Local dos experimentos}

Os experimentos foram desenvolvidos no Laboratório de Biotecnologia de Plantas Hortícolas do Departamento de Produção Vegetal da Escola Superior de Agricultura “Luiz de Queiroz” (ESALQ) e no Laboratório de Biotecnologia Vegetal do Centro de Energia Nuclear na Agricultura (CENA), ambos da Universidade de São Paulo (USP), em Piracicaba/SP.

\subsection{Transformações genética de citros}

\subsubsection{Origem, preparação e regeneração do material vegetal}

Para os ensaios com o gene bO utilizou-se a variedade porta-enxerto limão 'Cravo' (C. limonia Osbeck), enquanto que para cecropina optou-se pelas quatro variedades de laranja doce: 'Pêra', ‘Natal', 'Valência’ e 'Hamlin’ (C. sinensis L. Osbeck) que são as copas mais cultivadas no país. Por final os ensaios com o promotor da fenilalamina amônia-liase foram conduzidos com laranja 'Valência'.

Frutos maduros das variedades descritas acima foram colhidos na coleção de variedades do Departamento de Produção Vegetal (ESALQ/USP) e/ou obtidos em Instituições, como a Estação Experimental de Citricultura de Bebebedouro (EECB) e o Centro APTA Citros 'Sylvio Moreira'/IAC. Tiveram suas sementes extraídas, secas por 24 horas em temperatura ambiente e, posteriormente, descascadas e desinfestadas em 
solução 3:1 de água:hipoclorito de sódio (2,5\%), durante 20 minutos. Após este período, foram lavadas três vezes em água deionizada estéril, em condições assépticas e, incubadas in vitro em tubos de ensaio $(25 \times 125 \mathrm{~mm})$, contendo $10 \mathrm{~mL}$ do meio de cultura MT (Murashige \& Tucker, 1969), suplementado com 2 g.L ${ }^{-1}$ de phytagel e 25 g.L ${ }^{-1}$ de sacarose.

A incubação das sementes foi realizada em ausência de luz por 30 dias, à temperatura de $27{ }^{\circ} \mathrm{C}$, para o alongamento do epicótilo. Posteriormente, as plântulas foram transferidas para condições de fotoperíodo de 16 horas por 10-15 dias, estando prontas para retirada de explantes para os experimentos de transformação genética, que consistiu no corte de segmentos de epicótilo de aproximadamente 0,8 a 1,0 cm de comprimento.

\subsubsection{Linhagens de Agrobacterium utilizadas nos experimentos}

Nos ensaios com o limão 'Cravo', utilizou-se como vetor para transformação, Agrobacterium tumefaciens linhagem GV 3101, contendo o gene $b O$, dirigido pelo promotor 35S, com o gene de seleção nptII, que confere resistência ao antibiótico canamicina e o gene repórter gus (Figura 1). A construção foi gentilmente cedida pelo Dr. Eric Lam (The State University of New Jersey, USA)

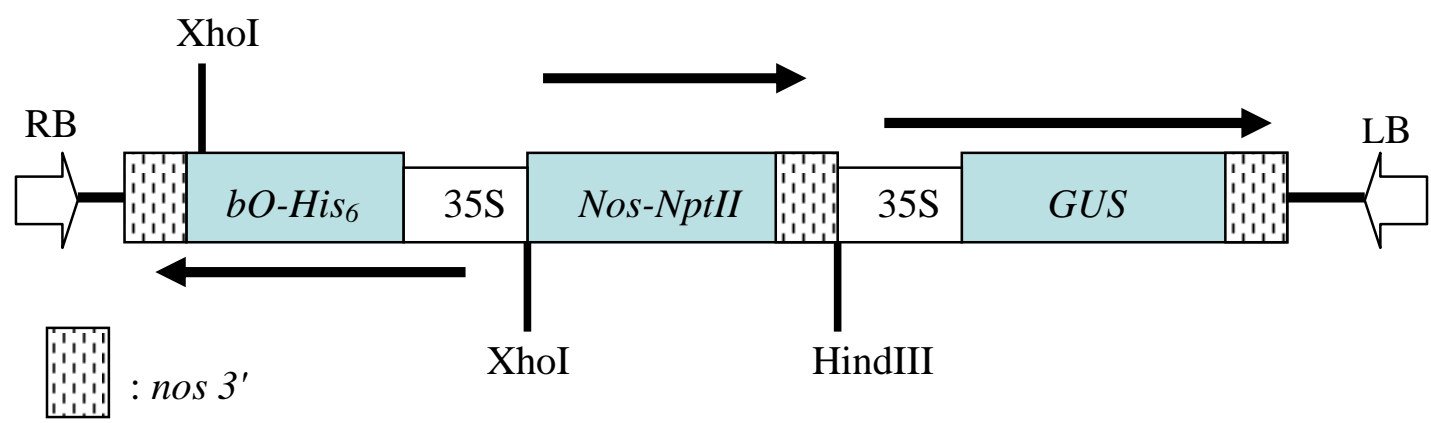

Figura 1 - Representação esquemática da construção utilizada nos experimentos de transformação genética de limão 'Cravo', com o gene $b O$, via Agrobacterium tumefaciens 
A linhagem GV 2260, contendo o gene cecropina (MB39), dirigido pelo promotor 35S e com o gene de seleção nptII, que confere resistência ao antibiótico canamicina, cedida pelo Dr. Ricardo Harakava (Instituto Biológico - São Paulo), foi utilizada como vetor para o sistema de transformação das laranjas doce (Figura 2).

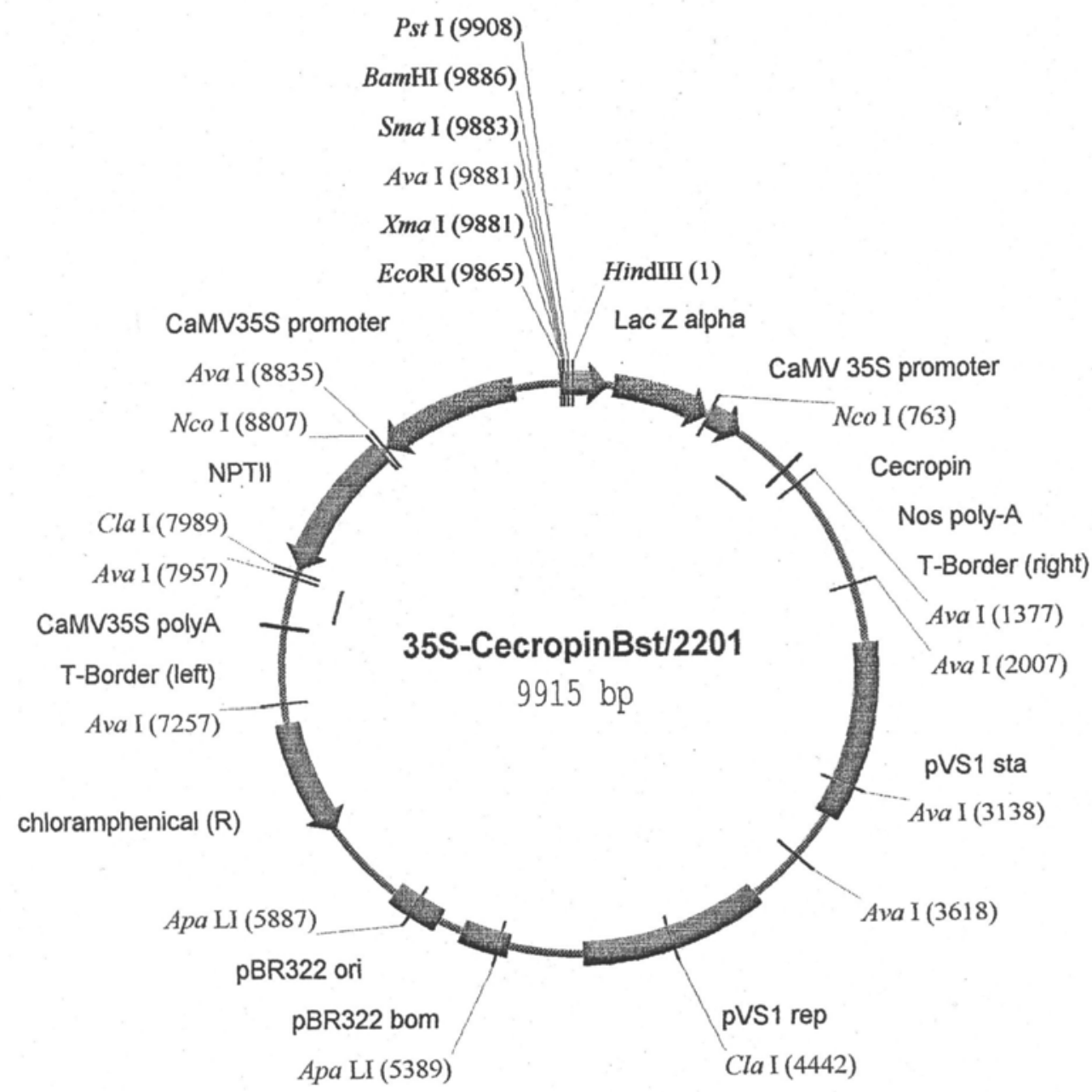

Figura 2 - Representação esquemática do plasmídeo pCAMBIA 2201 contendo o gene da cecropina, utilizado para as transformações das variedades copa de laranja doce 
Para os ensaios com o promotor da fenilalamina amônia-liase (PAL) utilizou-se como vetor para transformação, Agrobacterium tumefaciens linhagem GV 2260, contendo o plasmídeo pCAMBIA 2201, com o gene repórter gus, dirigido pelo promotor PAL de Citrus sinensis e o gene de seleção nptII, que confere resistência ao antibiótico canamicina (Figura 3). Essa construção também foi gentilmente cedida pelo Dr. Ricardo Harakava.

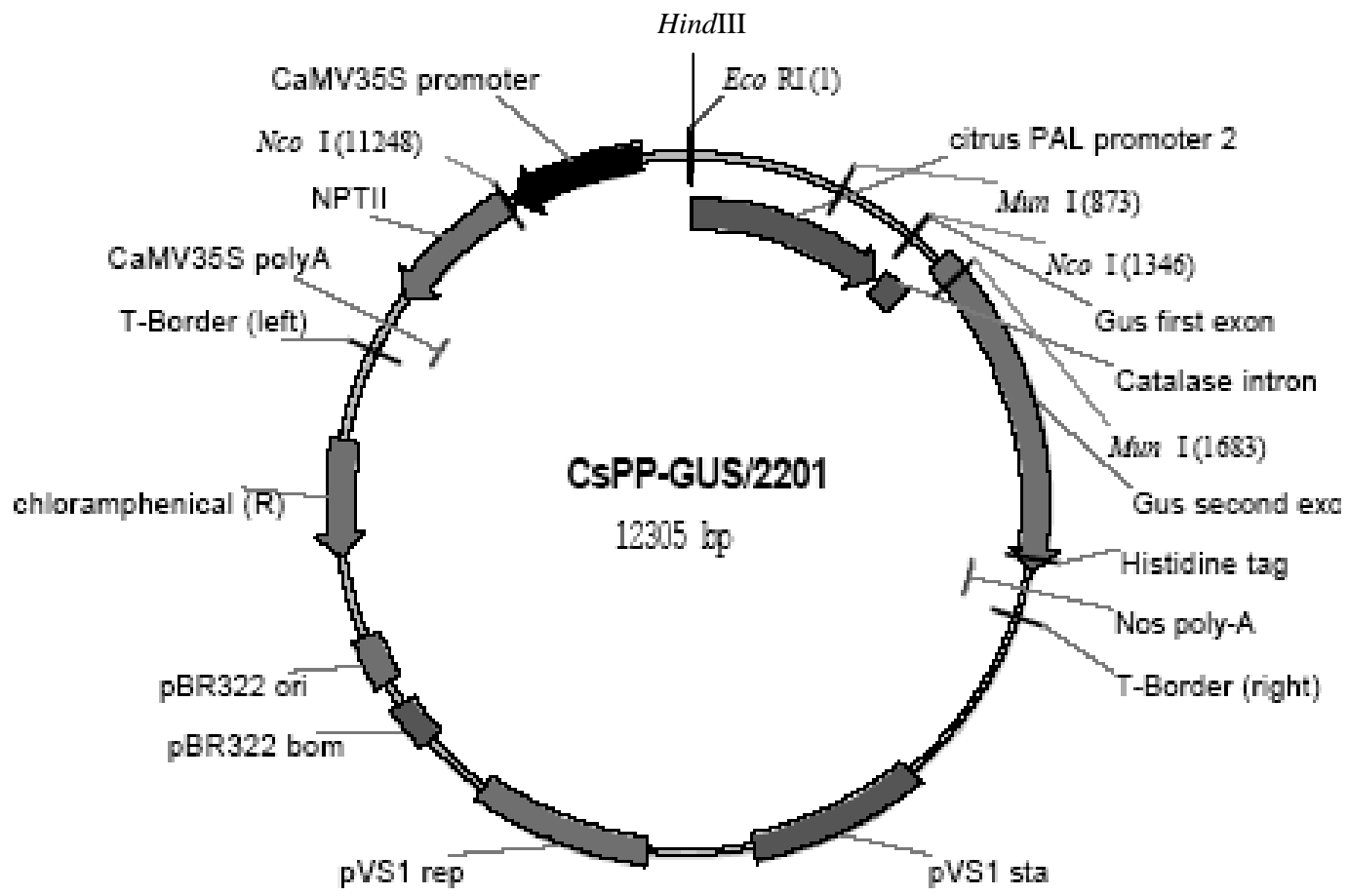

Figura 3 - Construção utilizada para a transformação genética de laranja 'Valência', utilizando o plasmídeo pCAMBIA 2201, com o promotor PAL de Citrus sinensis e o gene gus 


\subsubsection{Manutenção e cultivo de Agrobacterium tumefaciens}

Colônias isoladas de agrobactéria cultivada em meio sólido YEP (10 g.L $\mathrm{L}^{-1}$ de extrato de levedura, 5 g.L ${ }^{-1}$ de cloreto de sódio, 10 g.L ${ }^{-1}$ de peptona e 15 g.L ${ }^{-1}$ de agar), suplementado com os antibióticos para seleção da bactéria, por 76 horas, a $27^{\circ} \mathrm{C}$, foram transferidas para erlenmeyer (250 mL) com $50 \mathrm{~mL}$ do meio YEP líquido, suplementado com os antibióticos canamicina (100 mg. $\left.\mathrm{L}^{-1}\right)$ e rifamicina (50 mg. $\mathrm{L}^{-1}$ ) para a linhagem com o gene $b O$ e canamicina (100 mg. $\mathrm{L}^{-1}$ ) para as linhagens com a cecropina e o promotor da PAL. Ambas foram cultivadas sob agitação (180 rpm), a $28{ }^{\circ} \mathrm{C}$, por 16 horas.

A suspensão bacteriana foi quantificada em espectofotômetro (600 nm), ajustada para uma concentração de $5 \times 10^{8} \mathrm{UFC} / \mathrm{mL}$, centrifugada a $4800 \mathrm{rpm}$ (15 $\left.{ }^{\circ} \mathrm{C} / 20 \mathrm{~min}\right)$ e ressuspendida em meio líquido $\mathrm{MT}$ antes de serem inoculadas nos explantes. Quinzenalmente, os isolados foram transferidos para novo meio de cultura em placas de Petri e armazenados, após o crescimento (76 horas), a $4{ }^{\circ} \mathrm{C}$. Estoques dos isolados também foram mantidos em glicerol, a $-80^{\circ} \mathrm{C}$.

\subsubsection{Inoculação e co-cultivo}

Diversos experimentos foram conduzidos utilizando segmentos de epicótilo de 0,8-1,0 cm de comprimento de limão 'Cravo' e das variedades de laranjas doce descritas. Os explantes foram incubados na solução de bactéria $\left(5 \times 10^{8} \mathrm{UFC} / \mathrm{mL}\right)$ por 20 minutos em placa de Petri (58 x 15 mm). Posteriormente, foram enxugados em papel de filtro esterilizado e transferidos para placas de Petri $(100 \times 15 \mathrm{~mm})$ contendo o meio de regeneração MT sólido, suplementado com BAP (1 mg. $\left.\mathrm{L}^{-1}\right)$, onde foram co-cultivados na ausência de luz ( $23^{\circ} \mathrm{C}$ - limão ‘Cravo’ e $27^{\circ} \mathrm{C}$ - laranjas doce). 


\subsubsection{Seleção e regeneração de plantas}

Após três dias os explantes foram transferidos para o mesmo meio, contendo os antibióticos cefotaxime (500 mg. $\mathrm{L}^{-1}$ ) que inibe o crescimento de agrobactéria, e canamicina (100 mg. $\left.\mathrm{L}^{-1}\right)$ que seleciona os brotos transformados, mantidos nas mesmas condições do co-cultivo, e repicados a cada duas semanas, para estimular o desenvolvimento de gemas adventícias, quando foram, então transferidos para fotoperíodo de 16 horas de luz.

\subsubsection{Teste histoquímico de Gus e análises moleculares}

Pequenos segmentos de folhas e pecíolos dos experimentos com o gene $b O$ e o promotor PAL, respectivamente, foram incubados na ausência de luz a $37^{\circ} \mathrm{C}$, por 24 horas, na solução X-GLUC, para análise de $\beta$-glucoronidase - Gus (Jefferson, 1987).

DNA dos brotos regenerados, nos diversos ensaios, foi extraído de acordo com Dellaporta et al. (1983) para análise da PCR. Para confirmação da integração dos genes utilizados nas transformações ( $b O$, cecropina e gus) a amplificação foi realizada utilizando-se uma mistura composta de $1 \mu \mathrm{L}$ de DNA (50-100 ng), 0,2 $\mu \mathrm{L}$ de cada dNTP (10 mM), 1,0 $\mu \mathrm{L} \mathrm{MgCl}_{2}$ (25 mM), 2,0 $\mu \mathrm{L}$ de tampão (10x), 0,3 $\mu \mathrm{L}$ Taq polimerase (5 $\mathrm{u} / \mu \mathrm{L}$ ), mais 'primers' epecíficos. Todas as amostras foram submetidas ao termociclador (PTC-100 ${ }^{\mathrm{tm}}$, MJ Research, Inc.).

Para amplificação do gene $b O$ utilizou 0,3 $\mu \mathrm{L}$ de 'primer' (10 $\mu \mathrm{M})$ : 5' CAA GCT CAA ATT ACT GGA CGT CC3' e 5’CCG GAG CCT CAG CCT CAC CGA A3’. As reações foram submetidas às seguintes condições: 34 ciclos de 45 segundos a 95 C, 45 segundos a $52^{\circ} \mathrm{C}$ e 1 minuto a $72^{\circ} \mathrm{C}$ mais uma extensão final a $72^{\circ} \mathrm{C}$ por 2 minutos, para a amplificação de um fragmento de aproximadamente 750pb.

Os 'primers' cecropina - F - 5' ATG GGT AAG AAG TCT CAT ATT 3' e cecropina - R - 5' TCA ACC CAA AGC CTT AG 3' foram utilizados para PCR (0,3 $\mu \mathrm{L}$ cada), amplificando fragmento específico do gene cecropina (aproximadamente 211 bp). 
Utilizou-se termociclador programado a 34 ciclos de 30 segundos a $94{ }^{\circ} \mathrm{C}, 2$ minutos a $55^{\circ} \mathrm{C}$ e 1,5 minuto a $72{ }^{\circ} \mathrm{C}$.

A amplificação do gene gus foi realizada utilizando-se os primers: 5' CAA CGA ACT GAA CTG GCA G 3’ e 5’ CAT CAC CAC GCT TGG GTG 3’. As reações foram submetidas ao termociclador nas seguintes condições: 34 ciclos de 1 minuto a $92^{\circ} \mathrm{C}, 1$ minuto a $55^{\circ} \mathrm{C}$ e 1,5 minuto a $72^{\circ} \mathrm{C}$.

Análise de 'Southern blot' foi realizada para confirmar a integração estável dos genes nas plantas transgênicas. DNA total das plantas aclimatizadas foi extraído pelo método DNAzol (Plant DNAzol ${ }^{\circledR}$ ), acrescentando-se duas lavagens com fenol, para uma melhor purificação. Aproximadamente $20 \mu \mathrm{g}$ de DNA foram digeridos com as enzimas de restrição XhoI e HindIII (bO), EcoRI (cecropina) e HindIII e EcoRI (gus) separados em gel de agarose 1\% por eletroforese e transferidos para membrana de "nylon" (Hybond- $\mathrm{N}^{+}$, Amersham Biosciences). A sonda para o $b O$ foi preparada pela digestão de plasmídeo contendo o gene, que liberou o fragmento de 1,1 kb, enqanto que as sondas para cecropina e gus foram preparadas por PCR e os fragmentos amplificados de $750 \mathrm{pb}$ e $211 \mathrm{pb}$, correspondente, respectivamente a parte do gene, foram purificados. Todos os fragmentos foram submetidos à marcação com fluoresceína utilizando o kit "Gene Images ${ }^{\mathrm{TM}}$ Random Primer Labelling Module” (Amersham Biosciences). As hibridações foram realizadas a $60^{\circ} \mathrm{C}$ e as detecções com CDP-Star ${ }^{\mathrm{TM}}$ (Amersham Biosciences).

Para o 'Northern blot', RNA total de folhas das plantas de limão 'Cravo', transformadas com o gen $b O$, foi isolado usando Plant RNA Purification Reagent (Invitrogen) de acordo com as instruições do fabricante. Vinte gramas de RNA foi fracionado por eletroforese em gel de agarose a $0,8 \%$ contendo formaldeído e então transferido para membrana de nylon (Hybond- $\mathrm{N}^{+}$, Amersham Biosciences). A sonda do gene $b O$ gene foi preparada por PCR e o mesmo 'kit' utilizado para 'Southern blot' foi usado para a análise de 'Northern blot'. 


\subsubsection{Microenxertia e aclimatização das plantas transformadas}

Brotos Gus+ $(b O)$ e PCR+ (cecropina e PAL) foram enxertados in vitro em citrange 'Carrizo'. O preparo do porta-enxerto incluiu sua decaptação a 1,5-2,0 cm do epicótilo, redução do sistema radicular a 3,5-4,0 cm e remoção dos cotilédones e das gemas axilares. O meristema apical dos brotos transformados foi, então, enxertado na região terminal do epicótilo decapitado, estabelecendo contato com o sistema vascular.

Após 45 dias, as plantas foram aclimatizadas em vasos, contendo substrato comercial (Plantimax ${ }^{\mathrm{TM}} /$ Eucatex), mantidas sobre alta umidade (cobertura plástica), e permanecendo por 60 dias em câmara de crescimento (fotoperíodo $16 \mathrm{~h}, 40 \mu \mathrm{molm}^{-2} \mathrm{~s}^{-1}$ de intensidade luminosa e temperatura controlada de $27 \pm 2^{\circ} \mathrm{C}$ ). Após esse período, foram transferidas para vasos maiores e mantidas em casa de vegetação (Rendimax Citrus $^{\mathrm{TM}} /$ Eucatex).

\subsection{Avaliação de resistência a Phytophthora nicotianae em plantas de limão 'Cravo' transformadas geneticamente com o gene $b O$}

\subsubsection{Preparo das plantas}

Plantas de limão 'Cravo' transformadas geneticamente com o gene $b O$ foram multiplicadas por borbulhia, onde gemas de ramos maduros foram excisadas e enxertadas em porta-enxerto de limão 'Cravo'. Dez plantas de cada transgênico foram produzidas, seguindo o sistema de produção de mudas certificadas do Estado de São Paulo.

Da mesma forma, propagaram-se também plantas de limão 'Cravo' não transformado para servirem como controle (testemunha). Quando as plantas estavam com aproximadamente seis meses, por volta de 0,80 m de altura e com diâmetro de 3 $\mathrm{cm}$, à $10 \mathrm{~cm}$ do colo, fez-se o desponte das mesma e, 15 dias após as plantas estavam prontas para serem inoculadas com $P$. nicotianae. 


\subsubsection{Obtenção, seleção do inóculo e instalação do bioensaio}

Dez diferentes isolados de P. nicotianae foram obtidos na Unidade de Pesquisa e Desenvolvimento de Sorocaba, da APTA Regional, SAA. Antes da instalação do bioensaio, efetuou-se um pré-teste, com o intuito de selecionar o isolado mais agressivo. Plantas de limão 'Sicialiano' de oito meses de idade, com cerca de $70 \mathrm{~cm}$ de altura e 0,8 cm de diâmetro, foram inoculadas pelo método da agulha infestada com o patógeno (Siviero, 2000); que consistiu no perfuramento das hastes com agulha infestada, a altura de $10 \mathrm{~cm}$ do colo da planta. Em seguida, o ponto de inoculação foi protegido com algodão umedecido. As plantas foram mantidas em estufa telada. Os algodões foram umedecidos diariamente com água destilada, sempre no período da manhã. Quatorze dias após a inoculação, aferiu-se o comprimento e a largura da lesão e observou-se a presença de exsudação de goma.

O isolado selecionado foi inoculado em frutos de limão 'Siciliano' maduros, visando o reisolamento do patógeno. Um fragmento extraído da extremidade da lesão, de $0,6 \mathrm{~cm}$ de diâmetro, foi inoculado no albedo e os frutos foram mantidos à temperatura de $25^{\circ} \mathrm{C}$ com 16 horas de luz por nove dias.

Na seqüência, os frutos foram abertos cuidadosamente, após breve assepsia, em câmara de fluxo laminar. As sementes foram retiradas e colocadas individualmente em placas de Petri contendo cerca de $10 \mathrm{ml}$ do meio cenoura - CA (Kaosiri et al., 1978) e mantidas à temperatura de $25^{\circ} \mathrm{C}$ na ausência de luz.

Cinco dias após multiplicaram-se os propágulos iniciais em meio de cultura CA, para obtenção de maior quantidade de inóculo para a realização do ensaio. Quatro dias após a repicagem, as colônias de Phytophthora foram utilizadas para a instalação do bioensaio com as plantas transgênicas de limão 'Cravo'. As inoculações foram realizadas utilizando o método da agulha infestada (Siviero et al., 2000).

A avaliação do experimento foi realizada aos 25 dias após inoculação, consistindo na observação inicial da presença de exsudação de goma e de aferição do comprimento das lesões. A área das lesões foi mensurada em medidor de área (Licor ${ }^{\circledR}$ LI-3000). 


\subsection{Avaliação de resistência a Xanthomonas axonopodis pv. citri em folhas destacadas de laranja 'Valência' transformadas com o gene cecropina}

O bioensaio consistiu na inoculação de folhas destacadas pelo método de Franscischini et al. (2003). As folhas foram coletadas na estufa, de forma padronizada: sem sintomas de deficiência, na mesma posição na planta (intermediárias), tamanho semelhante, etc; em seguida foram lavadas em água corrente e então perfuradas com agulha de 0,56 mm e inoculadas com a imersão de solução contendo o patógeno.

O inóculo consistiu de uma suspensão de bactéria preparada a partir de colônias de três dias, as quais haviam sido plaqueadas em meio de cultura NA (peptona 5 g. $\mathrm{L}^{-1}$, extrato de levedura 1 g.L ${ }^{-1}$, extrato de carne 3 g.L ${ }^{-1}, \mathrm{NaCl} 8$ g.L $L^{-1}$ e agar 15 g.L ${ }^{-1}$ ) e incubadas a $28^{\circ} \mathrm{C}$. Utilizou-se uma concentração final de inoculo de $10^{6} \mathrm{UFC} / \mathrm{ml}$.

Tubos Falcon (50ml) formaram a unidade experimental, onde se manteve 0,5 mL de água estéril, e uma folha com o pecíolo, que foi mantido em contato com a água. Seis perfurações foram feitas em cada folha e para cada tratamento (transgênicos + testemunha) fez-se cinco repetições. Posteriormente, as folhas foram pulverizadas com o inóculo.

As avaliações consistiram na observação visual do aparecimento das primeiras lesões, anotando-se o tempo necessário para o aparecimento das mesmas, diariamente (incidência). Quinze dias após a inoculação as folhas foram digitalizadas e a severidade (percentagem da lesão em relação à área total da folha) foi determinada pelo software de quantificação de doença, Quant v.1 (Vale et al., 2001).

Os dados obtidos nos bioensaios foram submetidos à análise de comparação de médias pelo teste de Tukey $(P<0,05 \%)$. 


\section{RESULTADOS E DISCUSSÃO}

\subsection{Transformação genética de limão ‘Cravo’ com o gene $b O$}

\subsubsection{Regeneração de brotos e confirmação da transformação}

Duas brotações Gus-positivas de limão 'Cravo’ foram regeneradas dos explantes co-cultivados com A. tumefaciens. A inserção do gene $b O$ no genoma das plantas foi confirmada pela análise de PCR, mostrando a amplificação do fragmento esperado de aproximadamente $750 \mathrm{pb}$ nas duas plantas transgênicas. DNA das plantas PCR+ foi hibridizado com sonda específica para observação da integração do gene $b O$, confirmando a transformação com a ocorrência de três eventos de inserção do gene. Enquanto que a análise de 'Northern blot' confirmou a transcrição do gene nas plantas transformadas (Figura 4 a-d).

Há grande variação na eficiência de transformação genética nas diferentes espécies cítricas, sendo que melhores resultados têm sido obtidos com as laranjas doces (Citrus sinensis L. Osbeck), a exemplo da laranja ‘Hamlin’ (Mendes et al., 2002). Para limão 'Cravo' (Citrus limonia Osbeck) os resultados mostram baixa eficiência de transformação, permitindo dizer que há forte relação entre a espécie ou variedade na eficiência de transformação genética dos citros (Almeida et al., 2003). 


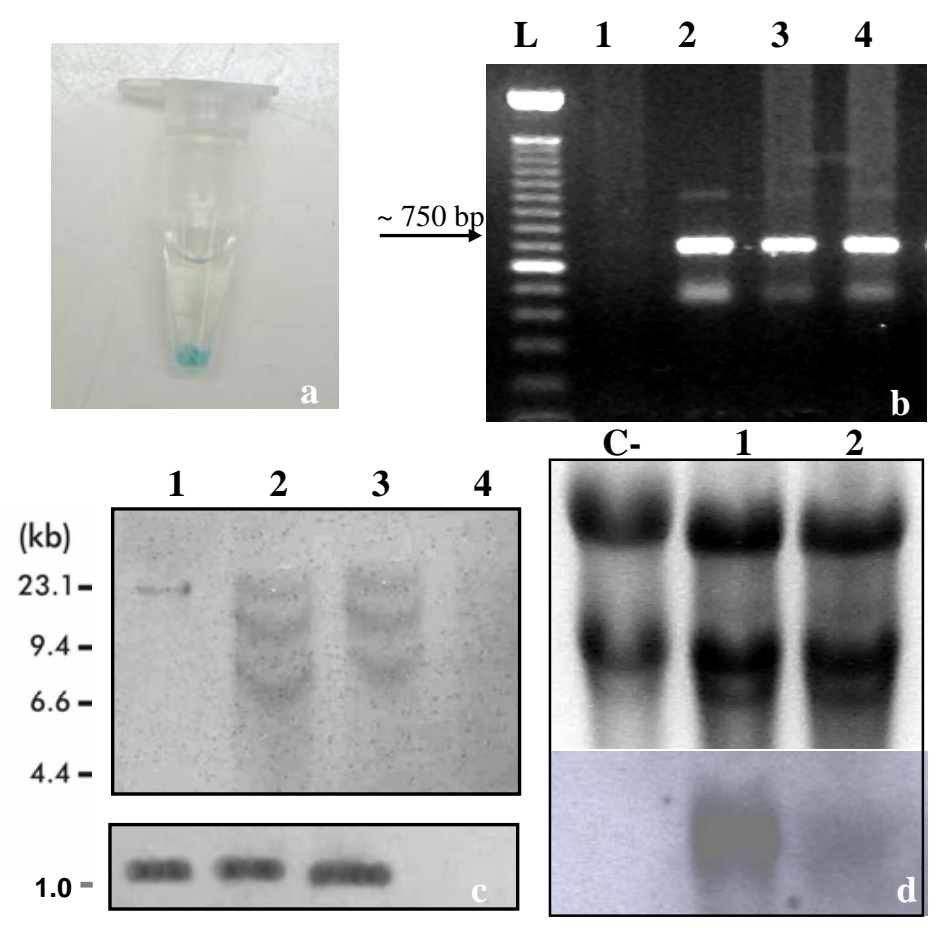

Figura 4 - Análises: histoquímica de Gus, PCR e Southern e Northern blot nas plantas transgênicas de limão 'Cravo'. a. Expressão do gene gus em broto transformado; b. PCR do DNA das plantas Gus+: L = ladder 100 bp; 1 e 2 = controles negativo e positivo, respectivamente; 3 e $4=$ plantas $b O+$; c. Detecção do gene $b O$ via 'Southern blot' com as enzimas HindIII (acima) e XhoI (abaixo): 1 = plasmídeo digerido como controle positivo; 2 e 3 = DNA das plantas $b O+; 4$ = DNA de planta não transformada (controle negativo). $\mathbf{d}$. 'Northern blot' - quantificação do RNA (acima) e níveis de transcrito do gene $b O$ nas plantas transgênicas (abaixo). C- = RNA de planta não transformada; 1-2 = RNA de plantas transformadas. 
Lesões semelhantes às de hipersensibilidade (HR) foram observadas nas duas plantas transgênicas de limão 'Cravo' obtidas, e mostrou maior intensidade de acordo com a idade das folhas. Variaram em forma e tamanho e foram usualmente amarelas (Figura 5 - direita). A formação espontânea de lesões na ausência do patógeno, denominada reação de $\mathrm{HR}$, tem sido relatada em um grande número de plantas transgênicas expressando genes como o bO (Mittler, 2000; Mohamed et al., 2001, Rizhsky \& Mittler, 2001). Em alguns casos, a ativação da morte programada de células é acompanhada pela indução de múltiplos mecanismos de defesa e na indução de resistência (Mittler \& Lam, 1996).
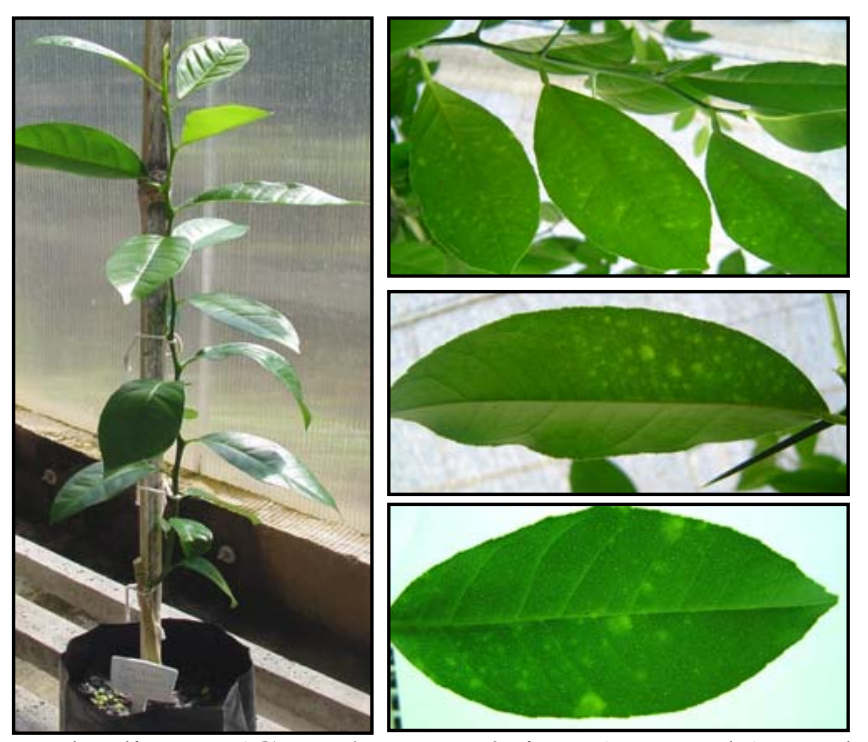

Figura 5 - Planta de limão 'Cravo' transgênica (esquerda) e detalhes das folhas mostrando lesões de hipersensibilidade relacionadas com a expressão do gene $b O$ (direita).

Este vem a ser o primeiro relato da transformação de citros com o gene $b O \mathrm{e}$ também a primeira introdução de gene de interesse no limão 'Cravo', porta-enxerto bastante cultivado no Brasil. O desenvolvimento das plantas transformadas ocorreu normalmente, sem haver mudanças no fenótipo da variedade (Figura 5 - esquerda), exceto a expressão de HR, descrita anteriormente. 


\subsubsection{Avaliação da resistência à Phytophthora nicotianae}

Inicialmente selecionou-se o isolado mais agressivo, com base nos resultados obtidos no pré-teste realizado (Tabela 1), para posterior instalação do bioensaio.

Tabela 1. Comprimento, largura $(\mathrm{cm})$ e presença de goma, nas lesões de $P$. nicotianae em hastes de plantas de limão 'Siciliano'

\begin{tabular}{lccc}
\hline Isolado & $\begin{array}{c}\text { Comp. lesão } \\
\text { (cm) }\end{array}$ & $\begin{array}{c}\text { Largura lesão } \\
(\mathbf{c m})\end{array}$ & $\begin{array}{c}\text { Presença de } \\
\text { goma }\end{array}$ \\
\hline 1. LRS 93/03 & 2,70 & 0,70 & Sim \\
2. LRS 95/03 & $\mathbf{2 , 8 0}$ & $\mathbf{1 , 5 0}$ & Sim \\
3. LRS 87/03 & 1,00 & 0,50 & Sim \\
4. LRS 90/03 & 2,00 & 1,20 & Não \\
5. LRS 94/03 & 2,00 & 0,70 & Sim \\
6. LRS 104/03 & 2,10 & 0,70 & Sim \\
7. LRS 99/03 & 1,00 & 0,30 & Não \\
8. LRS 98/03 & 1,70 & 0,70 & Sim \\
9. LRS 96/03 & 1,20 & 0,50 & Sim \\
10. LRS 97/03 & 0,30 & 0,40 & Não \\
\hline
\end{tabular}

Com base nos resultados obtidos selecionou-se o isolado LRS 95/03, que foi a fonte de inóculo para o bioensaio com as plantas de limão ‘Cravo’ transformadas com o gene $b O$ (Tabela 2).

Tabela 2. Porcentagem de plantas com goma, comprimento $(\mathrm{cm})$ e área $\left(\mathrm{cm}^{2}\right)$ das lesões causadas por P. nicotianae no lenho de plantas de limão 'Cravo'

\begin{tabular}{|c|c|c|c|}
\hline Tratamentos & $\begin{array}{c}\text { \% de plantas } \\
\text { com goma }\end{array}$ & $\begin{array}{c}\text { Comprimento } \\
\text { (cm) }\end{array}$ & $\begin{array}{l}\text { Área } \\
\left(\mathrm{cm}^{2}\right)\end{array}$ \\
\hline L. 'Cravo’ transgênico (Planta 1) & 30 & $0,90 \mathrm{~b}$ & $0.32 \mathrm{~b}$ \\
\hline L. 'Cravo’ transgênico (Planta 2) & 40 & $1,04 \mathrm{ab}$ & $0,46 a b$ \\
\hline L. ‘Cravo’’ & 60 & $1,37 \mathrm{a}$ & $0.54 \mathrm{a}$ \\
\hline CV (\%) & & 13,35 & 10,28 \\
\hline
\end{tabular}


A presença de goma foi observada em mais da metade das plantas de limão 'Cravo' (60\%). Por outro lado, as plantas transgênicas apresentaram considerável redução de exsudação, chegando a diminuir pela metade no caso da planta 1 (30\%). A presença de goma nas lesões, normalmente precede a rachadura da casca, que é um dos sintomas característicos da ocorrência de $P$. nicotianae em citros, que também incluem podridões de tronco, raízes e radicelas, portanto uma redução na exsudação resultará conseqüentemente, num menor agravamento da doença (Feichtenberger, 2000).

As duas plantas transgênicas apresentaram lesões menores que o limão 'Cravo' não transgênico, porém, apenas a planta 1 foi significativamente mais resistente (Figura 6), confirmando o alto nível do sinal de hibridização na análise de 'Northern blot'. Estes resultados podem ter ocorrido, pois a inserção do gene é aleatória, então, provavelmente na planta 1, a inserção ocorreu numa região de maior atividade de expressão. Fagoaga et al. (2001) citam que vários mecanismos estão envolvidos na modificação do sistema de defesa das plantas. A posição que o gene foi inserido e a expressão de proteínas e outros fatores integrados são importantes.

Há uma relação positiva entre as distintas aferições, apresentando coeficiente de correlação de 0,95 entre comprimento e área da lesão. Por isso a utilização da primeira leitura (comprimento), por ser simples e direta e dar um indicativo fiel dos resultados, em detrimento ao cálculo da área, pode ser considerada uma boa metodologia para quantificação da doença (Siviero et al., 2002).

Plantas expressando o gene $b O$ usualmente ativam a morte programada de células e podem apresentar resistência a fungos, pelo incremento nos níveis de ácido salicílico e a expressão de vários RNAs mensageiros relacionados com a patogenicidade, resultando na ativação da hipersensibilidade. Várias relações entre o patógeno e a planta, bem como os efeitos dos patógenos podem estar relacionados com a ativação e coordenação das respostas de defesa da planta, isso pode ser comprovado pela indução da hipersensiblidade em transgênico que ocorre na ausência do patógeno (McNellis et al., 1998). 
Plantas de tabaco expressando o gene $b O$ também mostraram aumento na resistência a patógenos como Pseudomonas syringae pv. tabaci (Mittler et al., 1995); mesma observação feita em batata, que apresentou resistência a fungos, devido ao incremento nos níveis de ácido salicílico, ativando a expressão de RNAs mensageiros relacionados com a patogenicidade, induzindo sistema de resistência adquirida - SAR (Abad et al., 1997).

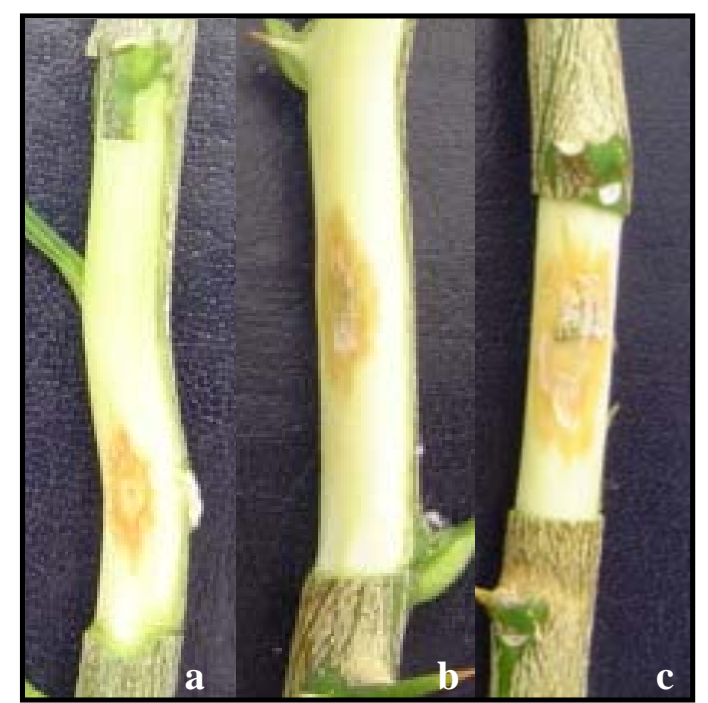

Figura 6 - Variações no tamanho das lesões de $P$. nicotianae em hastes de limão ‘Cravo': a - transgênico (planta 1); b - transgênico (planta 2) e; c - comum

Relata-se apenas um estudo relacionado à transgenia de citros para resistência à gomose de Phytophthora spp., realizado na Espanha. A transformação de laranja 'Pineapple' com a proteína PR-5 do tomate resultou na regeneração de nove plantas, constatando proteção contra Phytophthora citrophthora em alguns transgenênicos, que apresentaram alta sobrevivência na presença do patógeno após um ano. Por outro lado, não há trabalhos com porta-enxertos transgênicos voltados para a proteção a esta doença (Fagoaga et al., 2001). 


\subsection{Transformação genética de laranja doce com o gene cecropina}

\subsubsection{Regeneração dos brotos e confirmação dos transgênicos}

Transformaram-se as quatro variedades de laranja doce mais cultivadas no Brasil, utilizando-se protocolo de transformação via tecido juvenil (Figura 7 a-i). Maiores índices foram observados para as laranjas 'Valência’ (3,3-4,5 \%) e 'Hamlin’ (2,5-3,0 \%) em comparação com 'Natal' (1,6-2,0 \%) e 'Pêra (0,5\%), nos distintos experimentos (Tabela 3). Tal observação também foi feita por Boscariol (2004) transformando os mesmos materiais, porém utilizando os genes attA (atacina) e Xa21, comprovando que a eficiência do processo de transformação para citros é dependente da variedade utilizada.

Tabela 3. Número de gemas adventícias desenvolvidas, total de brotos PCR+, eficiência de transformação e total de plantas transgênicas de laranja doce transformadas com o gene cecropina

\begin{tabular}{lcccc}
\hline $\begin{array}{c}\text { Variedades de } \\
\text { laranja doce }\end{array}$ & $\begin{array}{c}\mathbf{N}^{\mathbf{0}} \text { de gemas } \\
\text { formadas/total } \\
\text { de explantes }\end{array}$ & $\begin{array}{c}\text { Total de } \\
\text { brotos } \\
\text { PCR+ }\end{array}$ & $\begin{array}{c}\text { Eficiência de } \\
\text { transformação } \\
\text { (\%) }\end{array}$ & $\begin{array}{c}\text { Total de plantas } \\
\text { aclimatizadas }\end{array}$ \\
\hline 'Hamlin' (exp1) & $84 / 300$ & 09 & 3,0 & 05 \\
'Hamlin' (exp2) & $62 / 200$ & 05 & 2,5 & 03 \\
'Hamlin' (exp3) & $185 / 400$ & 12 & 3,0 & 08 \\
'Valência' (exp1) & $39 / 150$ & 05 & 3,3 & 04 \\
'Valência' (exp2) & $163 / 400$ & 18 & 4,5 & 13 \\
'Valência' (exp3) & $36 / 100$ & 04 & 4,0 & 03 \\
'Natal' (exp1) & $63 / 400$ & 08 & 2,0 & 04 \\
'Natal' (exp2) & $75 / 500$ & 08 & 1,6 & 04 \\
'Pêra' (exp1) & $25 / 400$ & 02 & 0,5 & 01 \\
'Pêra' (exp2) & $28 / 600$ & 03 & 0,5 & 02 \\
\hline
\end{tabular}



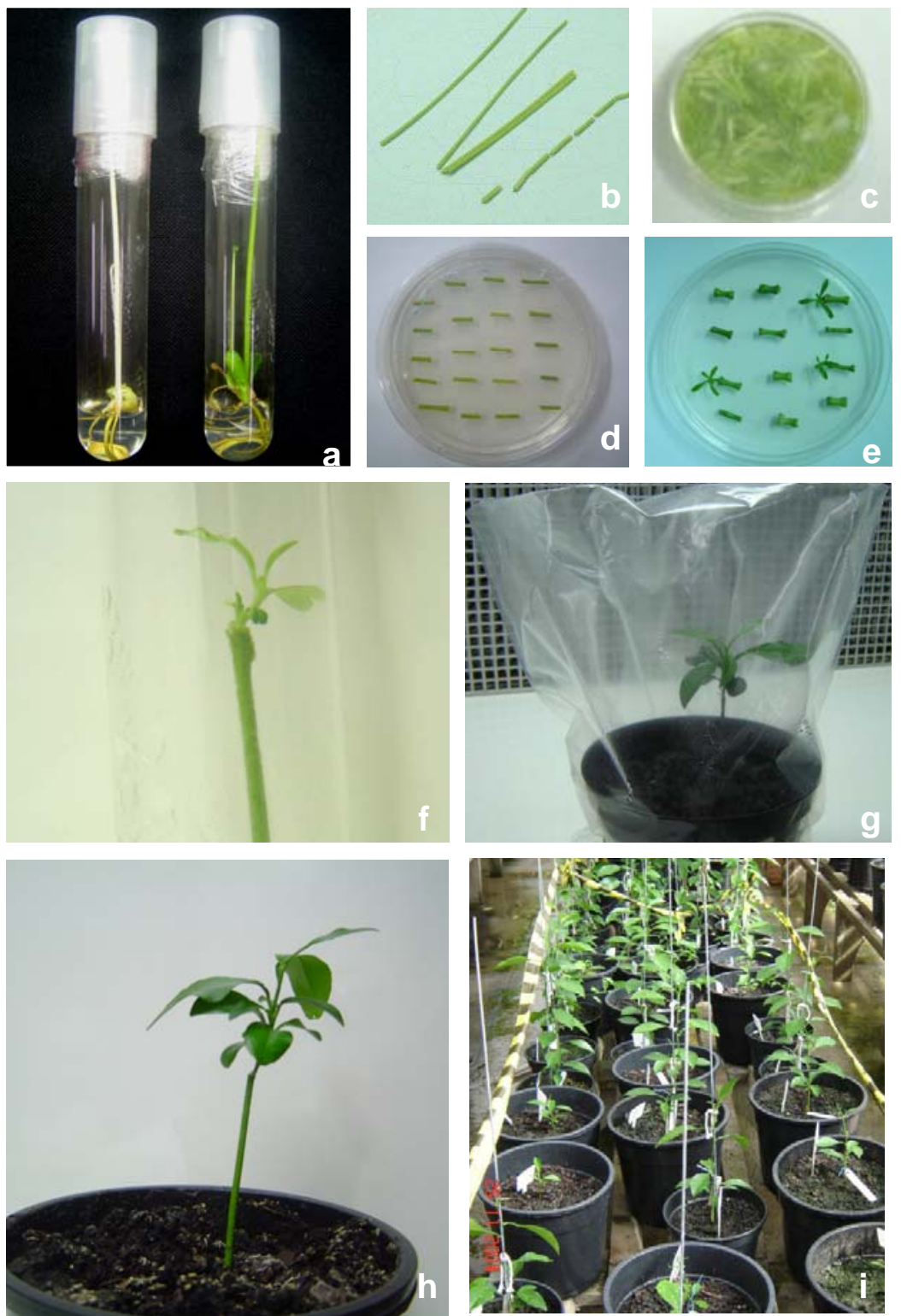

Figura 7 - Transformação genética de laranja doce com o gene cecropina a partir de tecido juvenil. a. Plântulas germinadas no escuro (esquerda), para estiolamento e, após período de 15 dias na luz (direita); b. Segmentos de epicótilo utilizados como fonte de explantes; c. Incubação com $A$. tumefaciens; d. Plaqueamento dos explantes em meio para co-cultivo; e. Regeneração de brotos em meio seletivo; f. Broto transgênico microenxertado; g. Início da aclimatização das plântulas em sala de crescimento; h. Finalização da fase de aclimataização; i. Plantas transgênicas em casa de vegetação 
A inserção do gene cecropina no genoma das plantas foi confirmada pela análise da PCR. Dos brotos avaliados, 26 de laranja 'Hamlin', 27 de laranja 'Valência', 16 de laranja 'Natal' e cinco de laranja 'Pêra' foram positivos, mostrando a amplificação do fragmento esperado de aproximadamente 211 pares de base (Figura 8 a-d).

DNA das plantas de laranja 'Valência' PCR+, já aclimatizadas em casa de vegetação, foi hibridizado com sonda específica para observação da integração do gene cecropina nas plantas transgênicas pela técnica de 'Southern blot'. Avaliaram-se plantas de laranja 'Valência', uma vez que as demais estavam em fase de aclimatização ou ainda in vitro, portanto não apresentavam folhas maduras, que são necessárias para extração de DNA. Confirmou-se a transformação com a ocorrência de pelo menos um evento de inserção do gene no genoma das mesmas (Figura 9).

A maioria das plantas transgênicas obtidas, com o gene cecropina, estão em casade-vegetação, e algumas em avançado desenvolvimento vegetativo. Nenhuma alteração fenotípica foi observada até o momento. 


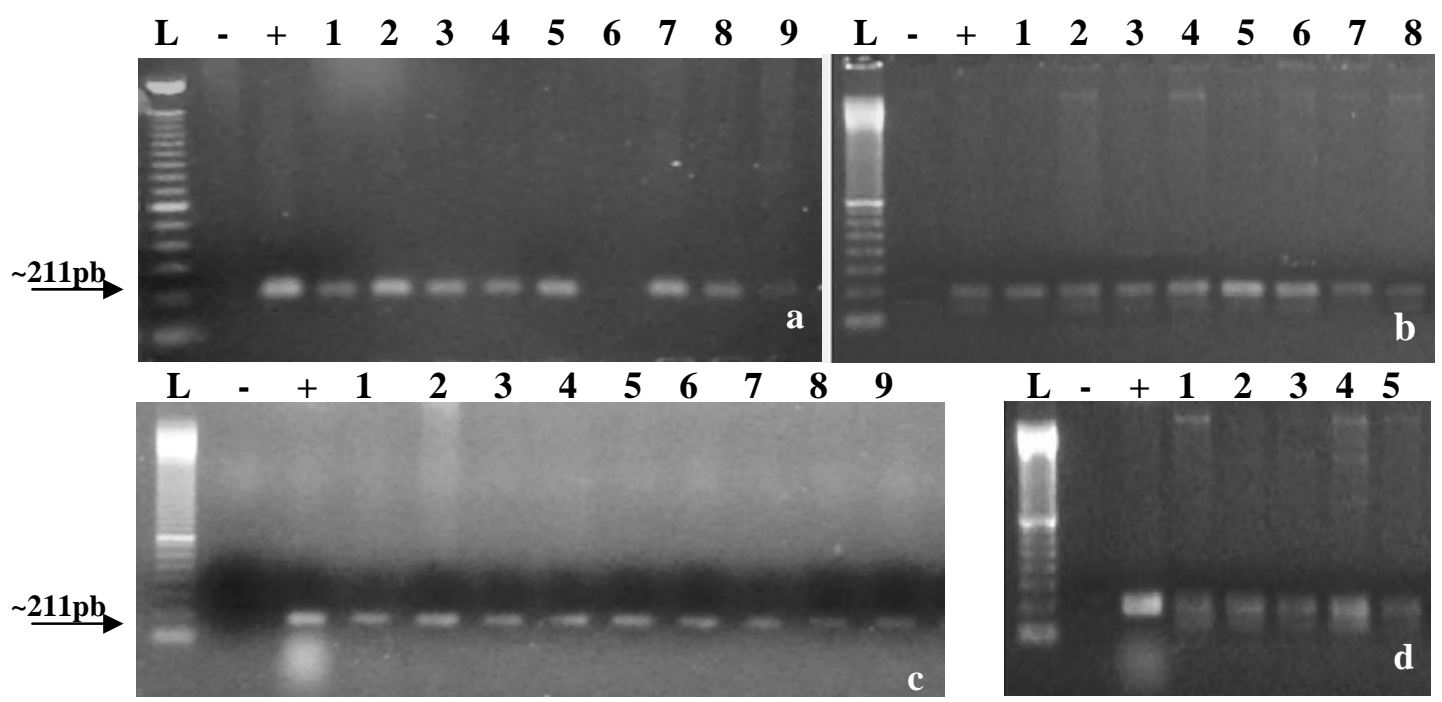

Figura 8 - Análise da PCR de brotos de laranja doce transformadas com o gene cecropina. a. laranja 'Hamlin'; b. laranja 'Valência'; c. laranja 'Natal' e, d. laranja 'Pêra'. $\mathrm{L}$ = ladder $100 \mathrm{pb}$; - = controle negativo (DNA planta não transformada); + = controle positivo (DNA bactéria); 1-9 representam brotos positivos (exceto 6 a)

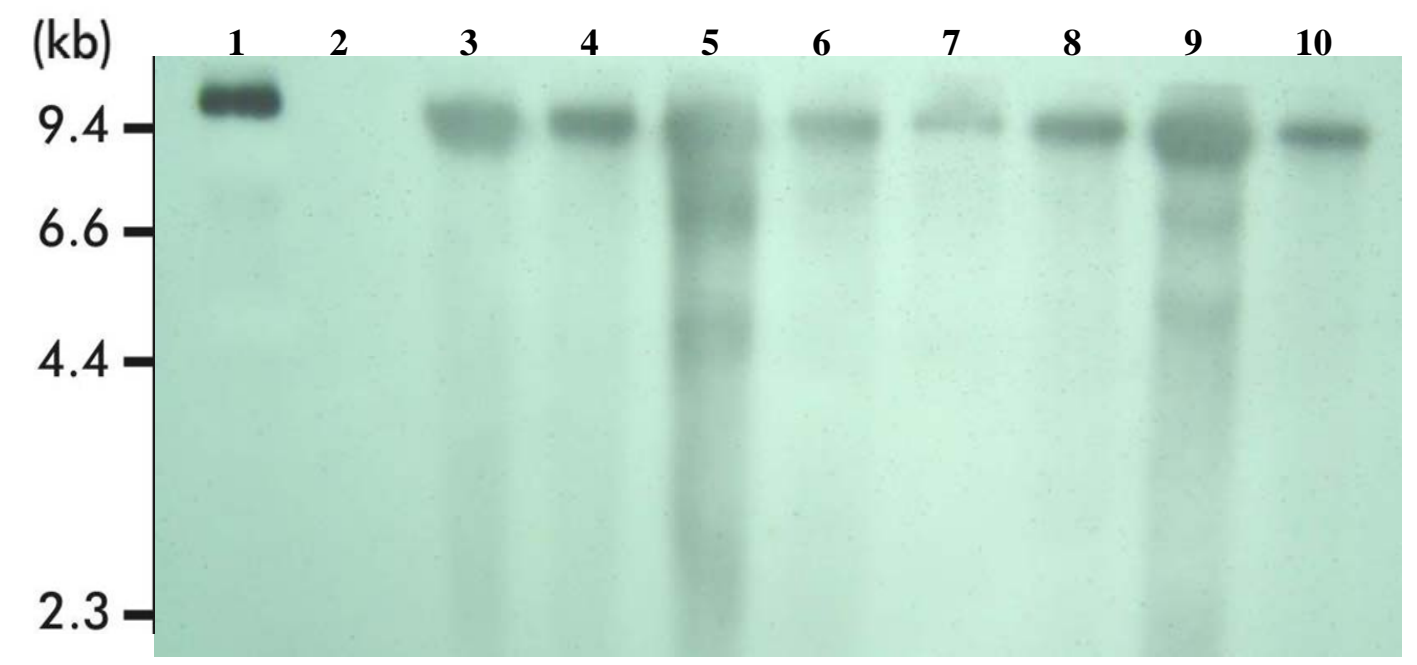

Figura 9 - Detecção do gene cecropina via 'Southern blot' em plantas de laranja 'Valência': 1 = plasmídeo pCAMBIA 2201 contendo o gene da cecropina digerido como controle positivo; 2 = DNA de planta não transformada (controle negativo) e; 3-10 = DNA das plantas Cecropina PCR+ $(\mathrm{DNA}$ digerido com a enzima EcoRI) 


\subsubsection{Avaliação de resistência a Xanthomonas axonopodis pv. citri em folhas destacadas de plantas de laranja 'Valência' transformadas com o gene cecropina}

Ensaios in vitro mostraram que peptídeos antimicrobianos são altamente tóxicos para algumas bactérias fitopatogênicas (Owens \& Heutte, 1997). Em citros há um relato da utilização de genes peptídos antimicrobianos, feito por Bespalhok et al. (2001), que descreveram ter transformado laranja 'Pêra' com o gene da sarcotoxina e, testes preliminares de inoculação com a bactéria causadora do cancro cítrico mostraram aumento significativo na resistência a esta doença. Assim, realizou-se um ensaio com esse objetivo.

As plantas de laranja 'Valência' transformadas com o gene da cecropina apresentaram melhores resultados perante o controle (planta de laranja 'Valência' não transformada), sendo que uma planta (3) apresentou-se significativamente mais tolerante, tanto na incidência quanto na severidade da doença (Figuras 10, 11 e 12).

Plantas de fumo, expressando o mesmo gene, também apresentaram aumento de resistência a doenças como, Pseudomonas syringae pv. tabaci e Erwinia carotovora subesp. carotovora (Ohshima et al., 1999). Já plantas de laranja ‘Hamlin’, transformadas com outro peptídeo antibacteriano, a atacina, também apresentaram uma redução nos sintomas apresentados em decorrência da inoculação do patógeno Xanthomonas axonopodis pv. citri, utilizando mesma metodologia descrita neste trabalho, mostrando a possibilidado do uso desse grupo de genes no controle do cancro cítrico (Boscariol, 2004). 


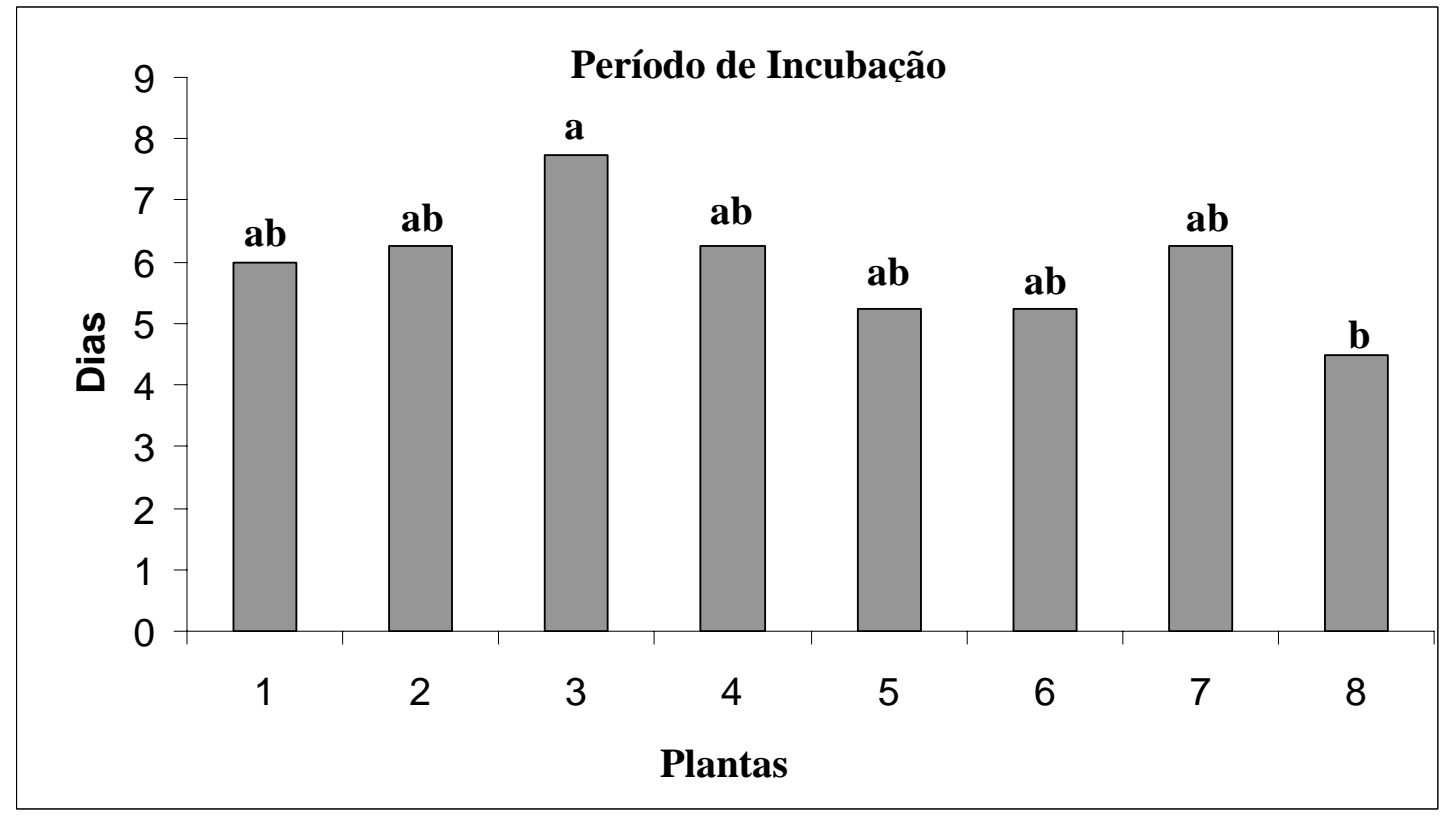

Figura 10 - Período médio de incubação (incidência), em dias, para o aparecimento dos primeiros sintomas de cancro cítrico em folhas de plantas de laranja 'Valência'. (1-7 = laranjas 'Valência' transgênicas e $8=$ controle, planta não transformada. Letras iguais não diferem significativamente (Tukey $5 \%)$

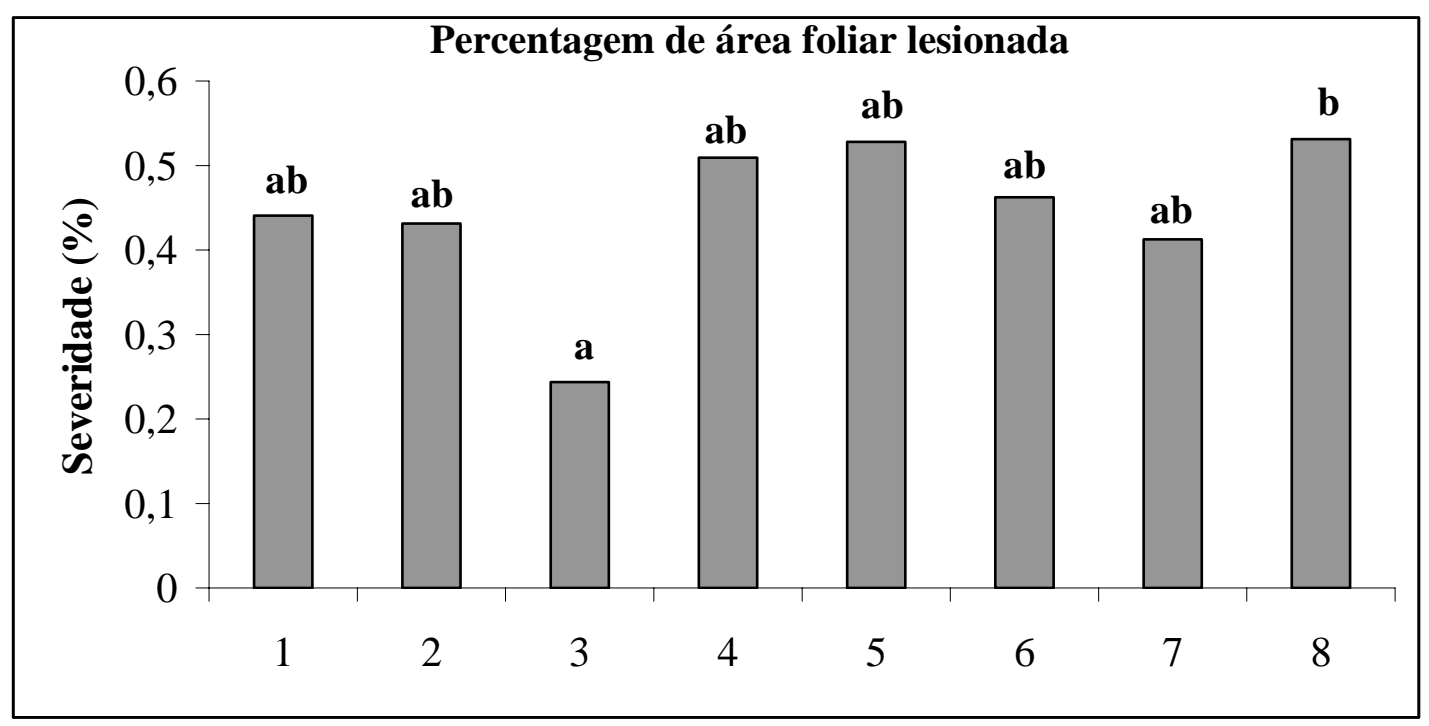

Figura 11 - Porcentagem da área da folhas de laranja 'Valência' lesionada sobre o total da área foliar (severidade). (1-7 = laranjas 'Valência' transgênicas e 8 = controle, planta não transformada. Letras iguais não diferem significativamente (Tukey - 5\%) 


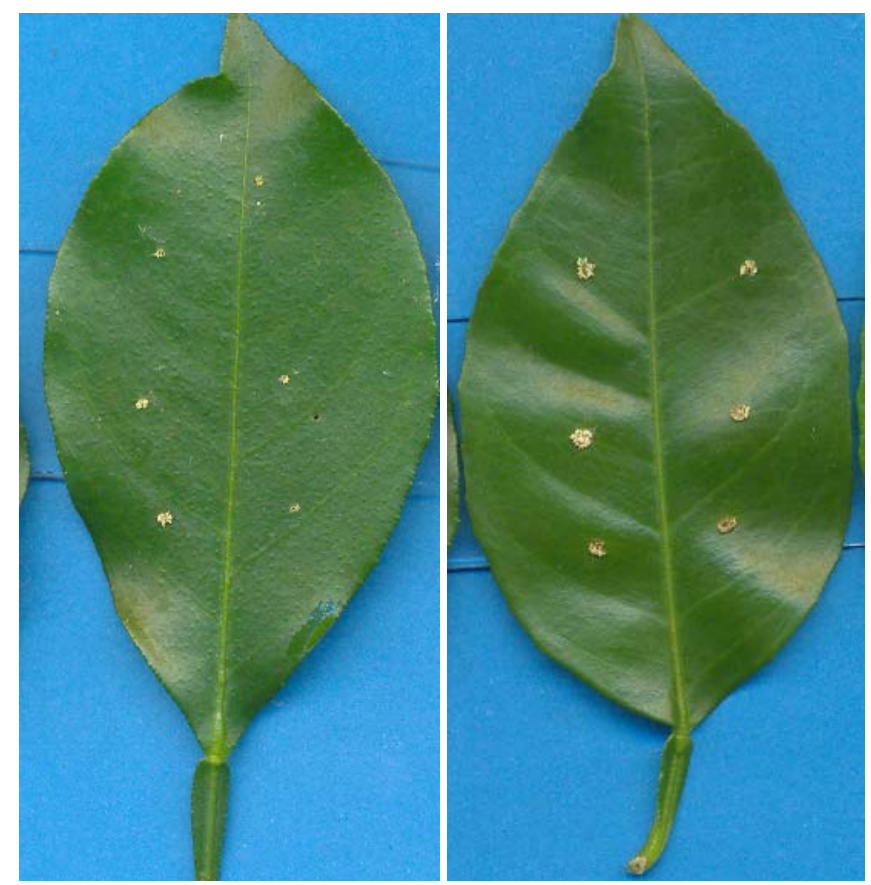

Figura 12 - Diferentes níveis de severidade nas lesões de cancro cítrico entre folha de planta transgênica (esquerda) e de planta testemunha (direita)

O sucesso da utilização desses peptídeos em estudos que visam aumentar resistência de plantas se deve a alguns pontos como: não são tóxicos para as plantas, têm rápida habilidade biostática contra células-alvo e à sua atividade em baixas concentrações (Reed et al., 1997). Além disso, compõem o sistema de defesa de espécies não vegetais e possuem um grande espectro de ação contra bactérias gram-positivas e gram-negativas (Mourgues et al., 1998).

A introdução de genes da família Xa21 do arroz também foi proposta para o controle do cancro cítrico (Guo \& Grosser, 2002). Esta família confere amplo espectro de resistência a X. oryzae pv. oryzae (Wang et al., 1996). Recentemente, no Brasil, as principais copas de laranja foram transformadas com este gene, visando aumento da resistência ao cancro cítrico (Boscariol (2004). 
É inegável que a transformação genética é uma alternativa viável e promissora para aumentar a resistência dos citros a doenças. Assim, tornam-se urgente a identificação e clonagem de genes envolvidos na resistência às mais diversas doenças e problemas da cultura. O protocolo utilizado para a transformação de laranja doce se mostrou eficiente na introdução do gene da cecropina, tornando possível a inserção de novos genes que possam contribuir para minimizar outros problemas da citricultura, tais como pragas e fatores abióticos. 


\subsection{Transformação genética de Citrus sinensis L. Osbeck com o promotor da} fenilalamina amônia-liase isolado de laranja doce

\subsubsection{Regeneração de brotos}

Foi possível a regeneração e confirmação de plantas transgênicas de laranja 'Valência', via Agrobacterium tumefaciens, contendo o gene repórter gus dirigido pelo promotor da fenilalamina amônia-liase de laranja doce (PALCs), a partir de segmentos juvenis de epicótilo (Figura 13 a-c), nos experimentos realizados (Tabela 4).

Tabela 4. Número de brotos de laranja 'Valência' regenerados e PCR positivo para o gene gus dirigido pelo promotor da fenilalamina amônia-liase.

\begin{tabular}{ccc}
\hline $\begin{array}{c}\text { Número de explantes } \\
\text { plaqueados }\end{array}$ & $\begin{array}{c}\text { Número de brotos } \\
\text { regenerados }\end{array}$ & $\begin{array}{c}\text { Número de brotos } \\
\text { PCR+ }\end{array}$ \\
\hline 150 (Exp1) & 67 & 08 \\
150 (Exp2) & 48 & 06 \\
\hline
\end{tabular}

Foram obtidos 14 brotos positivos, comprovados inicialmente pela análise da PCR (Figura $13 \mathrm{~d}$ ), quando as plantas estavam ainda in vitro e posteriormente, após aclimatização, por “Southern blot”, confirmando a inserção de pelo menos uma cópia do gene gus (Figura 13 e).

Este vem a ser o primeiro relato da transformação de plantas cítricas com o promotor da fenilalamina amônia-liase de citros clonado por Harakava (2000). Transformações utilizando esse promotor têm sido amplamente relatadas em tabaco (Gray-Mitsummune et al., 1999; Huang \& McBeath, 1994) e em Arabidopsis (Ohi et al., 1990; Giacomin \& Szalay, 1996; Rookes \& Cahill, 2003) e a expressão de genes reportes, como o gus ou o gfp, tem se mostrado na região do xilema. 


\subsubsection{Expressão do gene gus}

A expressão do gene gus pelo teste histoquímico se deu em apenas algumas (seis) plantas, apenas em segmentos de pecíolos, onde se concentram os vasos condutores, o que tem sido descrito previamente para promotores PAL isolados de outras plantas (Giacomin \& Szalay, 1996, Huang \& McBeath, 1994).

Em alguns segmentos de pecíolo observou-se expressão total do gene gus, enquanto que em outros se deu na região dos vasos condutores, mas não exclusivamente no xilema (Figura 13 f). Há relatos que a expressão de genes promovidos por promotores PAL pode ser induzida por fatores bióticos e abióticos, incluindo ferimentos, luz ultravioleta, infecções por patógenos, exposição a sais de metais pesados (Kervinen et al., 1998; Levee \& Seguin, 2001; Smith et al., 2001).

Gray-Mitsumune et al. (1999) transformaram Arabidopsis thaliana e tabaco com o gene gus utilizando o promotor PAL e análise histoquímica da atividade Gus nos transformantes primários mostraram que a atividade foi consistentemente localizada no sistema vascular de ramos, folhas, raízes e flores.

Plantas de tabaco tendo o gene gus dirigido por promotores PAL de Arabidopsis (Giacomin \& Szaly, 1996) e feijão (Bevan et al., 1989) mostraram expressão do gene repórter em células jovens, bem como em células do parênquima do xilema e em partes desenvolvidas da planta. Expressão do gene gus também pôde ser notada em células epidermais e tricomas, radicelas, pétalas, onde a produção de flavonóides requerem a atividade da enzima $P A L$.

A utilização de genes repórteres como a enzima beta glucoronidase, tem sido amplamente realizada para examinar a expressão do promotor PAL em tabaco (GrayMitsumune et al., 1999), A. thaliana e feijão. Porém esse método é destrutivo, assim outros estudos vêm utilizando o gene repórter da 'green fluorescent protein' (GFP), que pode ser visualizado facilmente em tecidos vivos, usando microscopia fluorescente convencional. Este método foi utilizado com sucesso por Rookies \& Cahill (2003) em A. thaliana. 

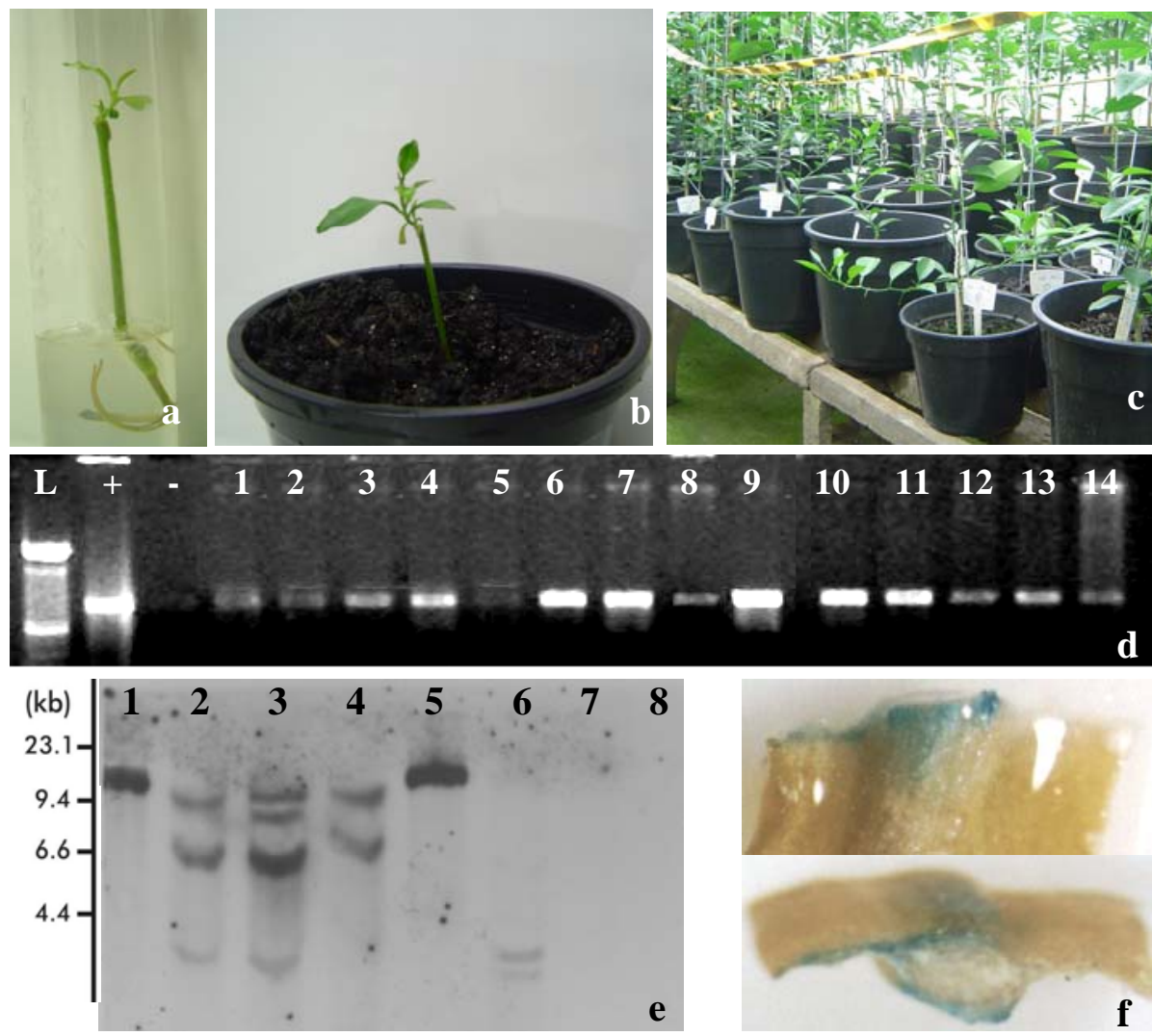

Figura 13 - Seqüência da transformação de laranja 'Valência' com o gene gus e o promotor PAL. a. Microenxertia de broto Gus+; b. Plântula préaclimatizada em sala de luz; c. Aclimatização das plantas em casa de vegetação; d. Análise de PCR: L = ladder 100pb; + e - = controles positivo e negativo, respectivamente; 1-14 = plantas Gus+; e - Análise de 'Southern blot': 1 e 5 = controles positivo (plasmídeo digerido com enzimas HindIII e EcoRI, respectivamente); 7-8 = controle negativo (DNA de planta não transformada digerido com enzimas HindIII e EcoRI, respectivamente); 2-4 = DNA das plantas de 'Valência'transgênicas digerido com a enzima HindIII e; 6 = DNA das plantas de 'Valência'transgênicas digerido com a enzima EcoRI; f. Expressão do gene gus, na região vascular de pecíolos de folhas de laranja 'Valência'(aumento $10 \mathrm{x}$ ). 


\section{CONCLUSÕES}

a) O sistema de transformação mediado por Agrobacterium tumefaciens, utilizando segmentos de epicótilo é viável para Citrus sp, uma vez que foi possível transformar as variedades com as construções propostas;

b) Diferentes taxas de eficiência na transformação genética entre as variedades e espécies de citros foram observadas, mostrando haver alta influência do genótipo no sistema mediado pela Agrobacterium;

c) Os genes bacteriopsina e cecropina apresentam potencial para serem incorporados em programas de melhoramento visando resistência a Phytophthora spp. e Xanthomonas axonopodis pv. citri, respectivamente;

d) A utilização do promotor isolado de laranja doce (PAL), visando expressão de genes nos vasos do xilema, não mostrou-se uma alternativa viável para futuras transformações de Citrus sinensis com genes visando resistência a Xylella fastidiosa. 


\section{REFERÊNCIAS BIBLIOGRÁFICAS}

ABAD, M.S.; HAKIMI, S.M.; KANIEWSKI, W.K.; ROMMENS, C.M.T.; SHULAEV, V.; LAM, E.; SHAH, D.M. Characterization of acquired resistance in lesion-mimic transgenic potato expressing bacterio-opsin. The American Phytopathological Society, v.10, n.5, p.635-645, 1997.

ALMEIDA, W.A.B.; MOURÃO FILHO, F.A.A., MENDES, B.M.J.; PAVAN, A.; RODRIGUEZ, A.P.M. Agrobacterium-mediated transformation of Citrus sinensis and Citrus limonia epicotyl segments. Scientia Agricola, v.60, n.1, p.23-29, 2003.

AMORIM, E.P.R. Controle biológico de Phytophthora parasitica Dastur e Phytophthora citrophthora (Smith \& Smith) Leonian em plântulas de citros. Botucatu, 1997. 113p. Tese (Doutorado) - Faculdade de Ciências Agrárias, Universidade Estadual Paulista “Júlio de Mesquita Filho”.

ANDERSEN, P.C.; ISHIDA, M.L.; MOMOL, E.A.; BRODBECK, B.V; LEITE, B.; MOMOL, M.T. Influence of Vitis xylem fluid and xylem fluid plus cecropin on growth of Xylella fastidiosa Vitis, v.43, n.1, p.19-25, 2004.

BERGAMIN FILHO, T.; AMORIM, L.; LARANJEIRA, F.; GOTTWALD, T.R.

Epidemiology of citrus canker in Brazil with and without the Asian citrus leafminer. In: INTERNATIONAL CITRUS CANKER RESEARCH WORKSHOP, Ft. Pierce, Fl, 2000. Proceedings. Florida, 2000. p.20-22. 
BESPALHOK, F.J.C.; KOBAYASHI, A.K.; PEREIRA, L.F.P.; VIEIRA, L.G.E. Laranja transgênica: transformação de laranja visando resistência ao cancro cítrico usando genes de peptídeos antibacterianos. Biotecnologia Ciência \& Desenvolvimento, v.28, p.229-234, 2001.

BEVAN, M.; SHUFFLEBOTTOM, D.; EDWARDS, K.; JEFFERSON, R.; SHUCH, W. Tissue and cell-specific activity of a phenylalamine ammonia-lyase promoter in transgenic plants. EMBO Journal, v.18, p.1899-1906, 1989.

BOMAN, H.G.; HULTMARK, D. Cell-free immunity in insects. Annual Review Microbiology, v.41, p.103-126, 1987.

BORÉM, A.; MILACH, S.C.K. Melhoramento de plantas. Biotecnologia Ciência \& Desenvolvimento, v.2, n.7, p.68-72, 1999.

BOSCARIOL, R.L. Transformação genética de laranja doce com os genes manA, atacina A e Xa21. Piracicaba, 2004. 87p. Tese (Doutorado) - Centro de Energia na Agricultura, Universidade de São Paulo.

BOSCARIOL, R.L; ALMEIDA, W.A.B.; DERBYSHIRE, M.T.V.C.; MOURÃO FILHO, F.A.A.; MENDES, B.M.J. The use of the PMI/mannose selection system to recover transgenic sweet orange plants (Citrus sinensis L. Osbeck). Plant Cell Report, v.22, p'.122-128, 2003.

BRASILEIRO, A.C.M.; DUSI, D.M.A. Transformação genética de plantas. In: TORRES, A.C.; CALDAS, L.S.; BUSO, J.B. Cultura de tecidos e transformação genética de plantas. Brasília: EMBRAPA-SPI / EMBRAPA-CNPH, 1999. 863p. v.2.

BROADBENT, P. Rootstock tolerance to biotic stress. In: INTERNATIONAL SOCIETY OF CITRICULTURE. Flórida, 1997. Proceedings. Florida:ISC, p. 12551257, 1997. 
CARLOS, E.F. Transmissão do declínio dos citros. Fundecitrus, v.12, n.79, p.3-4, 1996.

CARMONA, M.J.; MOLINA, A.; FERNANDEZ, J.A.; LOPEZFANDO, J.J.; GARCIALOLMEDO, F. Expression of the alpha-thionin gene from barley in tobacco confers enhanced resistance to bacterial pathogens. Plant Journal, v.3, p.457-462, 1993.

CEPEA. http://www.cepea.esalq.usp.br/indicador/citros/cepea_citricultura_jun 04.pdf (14 jan. 2005)

CERVERA. M.; ORTEGA, C.; NAVARRO, A.; NAVARRO, L.; PEÑA, L. Generation of transgenic citrus plants with the tolerance-to-salinity gene HAL2 from yeast. Journal of Horticultural Science \& Biotechnology, v.75, p.26-30, 2000.

CERVERA, M.; JUÁREZ, J.; NAVARRO, A.; PINA, J.A.; DURÁN-VILA, N.; NAVARRO, L.; PEÑA, L. Genetic transformation and regeneration of mature tissues of woody fruit plants bypassing the juvenile stage. Transgenic Research, v.7, p.51-59, 1998.

CHRISTENSEN, B.; FINK, J.; MERRIFIELD, R.B.; MAUZERALL, D. Channelforming properties of cecropins and related model compounds incorporated into planar lipid membrana. Proceedings of National Academy Science USA, v.85, p.5072-5076, 1988.

COLETA-FILHO, H.D.; MACHADO, M.A. Evaluation of the genetic structure of Xylella fastidiosa populations from different Citrus sinensis varieties. Applied and Environmental Microbiology, v.68, n.8, p. 3731-3736, 2002.

COMISSÃO TÉCNICA NACIONAL DE BIOSSEGURANÇA. Lei de biossegurança ${ }^{\circ}$ 11.105. http//:www.ctnbio.gov.br (03 mai.2005) 
DELLAPORTA, S.L.; WOOD, J.; HICKS, J.B. A plant DNA minipreparation: version II. Plant Molecular Biology Reporter, v.4, p.19-21, 1983.

DEZOTTI, D.F.; CRISTOFANI, M.; AMARAL, A.M.; TAKITA, M.A.; CARVALHO, S.A.; MACHADO, M.M. Obtenção de brotações adventícias in vitro de laranjas doces a partir de tecido adulto visando transformação para resistência ao cancro cítrico (compact disc) In: CONGRESSO BRASILEIRO DE FRUTICULTUA, 18, 2004, Florianópolis, Anais. Florianópolis: SBF, 2004.

DOMÍNGUES, A.; GUERRI, J.; CAMBRA, M.; NAVARRO, L.; MORENO, P.; PEÑA, L. Efficient production of transgenic citrus plants expressing the coat protein gene citrus tristeza virus. Plant Cell Reports, v.19, p.427-433, 2000.

DOMINGUES, E.T.; TULMANN NETO, A. Bancos de germoplasma de citros e sua importância para o melhoramento. Laranja, v.19, n.2, p.343-364, 1998.

DONADIO, L.C.; MOREIRA, C.S. Citrus variegated chlorosis. Bebedouro: Fundecitrus, 1998. 166p.

ERWIN, D. C.; RIBEIRO, O. K. Phytophthora diseases worldwide. St. Paul, Minn: APS Press, 1996. 562p.

FAGOAGA, C.; RODRIGO, I.; CONEJERO, V.; HINAREJOS, C.; TUSET, J.J.; ARNAU, J.; PINA, J.A.; NAVARRO, L.; PEÑA, L. Increased tolerance to Phytophtora citrophthora in transgenic orange plants constitutively expressing a tomato pathogenesis related protein PR-5. Molecular Breeding, v. 7, p.175-185, 2001.

FAO. Databasis http://apps.fao.org. (14 jan. 2005)

FEBRES, V.J.; NIBLETT, C.L.; LEE, R.F.; MOORE, G.A. Characterization of grapefruit plants (Citrus paradisi Macf.) transformed with citrus tristeza closterovirus genes. Plant Cell Reports, v.21, p.421-428, 2003. 
FEICHTENBERGER, E. Manejo ecológico das principais doenças fúngicas e bacterianas dos citros no Brasil. In: SEMINÁRIO INTERNACIONAL DE CITROS: Tratos Culturais, 5., Bebedouro, 1998. Anais , Bebedouro: Fundação Cargill,1998, p. 23-63: Tratos Culturais

FEICHTENBERGER, E. Manejo integrado das principais doenças dos citros no Brasil. In: SEMINÁRIO INTERNACIONAL DE CITROS, 6., Bebedouro,2000 Anais. Bebedouro:, Fundação Cargill, 2000. p. 176-216: Produção integrada

FERNANDES, G.W.; MARTINS, R.P. As galhas: tumores de plantas. Ciência Hoje, v.4, n.19, p.58-64, 1985.

FIGUEIREDO, J.O. Variedades copa de valor comercial. In: RODRIGUEZ, O.; VIÉGAS, F.; POMPEU JUNIOR, J.; AMARO, A.A. Citricultura brasileira. Campinas: Fundação Cargill, 1991. p.228-264.

FLEMING, G.H.; OLIVARES-FUSTER, O.; FATTA DEL-BOSCO, S. GROSSER, J.W. An alternative method for the genetic transformation of sweet orange. In Vitro Cellular Development Biology, v.36, p.450-455, 2000.

FRANCISCHINI, F.J.B.; BONINI, M.; BELASQUE JÚNIOR, J.; RODRIGUES NETO, J. Detecção e diagnose do cancro cítrico (Xanthomonas axonopodis pv. citri) em folhas destacadas de limão Cravo. Summa Phytopathologica, v.29, n.1, p.52, 2003.

FROST, H.B.; SOOST, R.K. Seed reproduction: development of gametes and embryos. In: REUTHER, W.; WEBBER, H.J.; BATCHELOR, L.D. (Ed). The Citrus Industry. Berkeley: California Division of Agricultural Sciences, University of California, 1968. v.2, p.291-300.

FUNDECITRUS. Cancro cítrico volta a ameaçar região nobre da citricultura. Manual técnico do cancro cítrico. Araraquara: Fundecitrus, 1997, 11p. (Boletim Técnico). 
FUNDECITRUS. http://www.fundecitrus.com.br. (21 jan.2005).

GIACOMIN, L.J.; SZALAY, A.A. Expression of a PAL1 promoter luciferase gene fusion in Arabidopsis thaliana in response to infection by phytopathogenic bacteria. Plant Science, v.116, p.59-72, 1996.

GMITTER JUNIOR, F.G.; GROSSER, J.W.; MOORE, G.A. Citrus. In: HAMMERSCHLAG, F.A.; Litz, R.E. (Ed.). Biotechnology of perennial fruit crops. Wellingford: CAB International, 1992. p.335-369.

GRAVENA, S. O cancro e a Minadora. Informativo Coopercitrus, v. 12, n.141, p.18, 1998.

GRAY-MITSUMMUNE, M.; MOLITOR, E.K.; CUKOVIC, D; CARLSON, J.E.; DOUGLAS, C.J. Developmentally regulated patterns of expression directed by poplar PAL proomoters in transgenic tobbaco and poplar. Plant Molecular Biology, v.39, p. 657-669, 1999.

GROSSER, J.W.; GMITTER JUNIOR, F.G. Protoplast fusion and Citrus improvement. Plant Breeding Reviews, v.8, p.339-374, 1990.

GUIDETTI-GONZALEZ, S.; PESTANA-CALSA, M.C; CARRER, H. Transformação genética de Catharanthus roseus com o gene bO (bacteriopsina) visando resistência à Xylella fastidiosa. In: SIMPÓSIO INTERNATIONAL DE INICIAÇÃO CIENTÍFICA DA USP, 9., Piracicaba, 2001. Anais Piracicaba: USP, 2001, v.1, p. 11-16.

GUTIÉRREZ-E, M.A.; LUTH, D.; MOORE, G.A. Factors affeting Agrobacteriummediated transformation in Citrus and production of sour orange (Citrus aurantium L.) plants expressing the coat protein gene of citrus tristeza virus. Plant Cell Reports, v.16, p.745-753, 1997. 
GWO, W.W.; GROSSER, J.W. Transgenic sweet orange plant regeneration by protoplast co-transformation with a potencial cancer resistence gene and a GFP marker gene. In: INTERNATIONAL CITRUS CONGRESS, Agadir: ISC, 2004. Resumos. Agadir, Mar., 2004. p.30.

HANCOCK, R.E.; LEHRER, R. Cationic peptides: a new souce of antibiotics. Trends Biotechnology, v.16, p.82-88, 1998.

HARAKAVA, R. Citrus variegated chroloris: development of transgenic resistance and molecular studies of pathogenesis. 2000. 70p. Thesis (Doctory). University of Florida.

HIDAKA, T.; OMURA, M. Transformation of citrus protoplasts by electroporation. Journal of Japanese Society of Horticultural Science, v.62, p.371-376, 1993.

HIDAKA, T.; OMURA, M.; UGAK, M.; TOMIYAMA, M.; KATO, A.; OHSHIMA, M.; MOTOYOSHI, F. Agrobacterium-mediated transformation and regeneration of Citrus spp. from suspension cells. Japanese Journal of Breeding, v.40, p.199-207, 1990.

HUANG, Y.; McBEATH, J.H. Bacterial induced activation of an Arabidopsis phenylalamine ammonia-lyase promoter in transgenic tobacco plants. Plant Science, v.98, p.25-30, 1994.

JAYNES, J.M.; NAGPALA, P.; DESTEFANO-BELTRAN, L.; HONG-HUNG, J.; KIM, J.; DENNY, T.; CETINER, S. Expression of a cecropin B lytic peptide analogue in transgenic tobacco confers enhanced resistance to bacterial wilt caused by Pseudomonas solanacearum. Plant Science, v. 8, p.43-53, 1993.

JEFFERSON, R.A. Assaying chimeric genes in plants: the GUS gene fusion system. Plant Molecular Biology Reporter, v.5, p.387-405, 1987. 
KAOSIRI, T.; ZENTMYER, G.A.; ERWIN, D.C. Stalk length as a taxonomic criterion for Phytophthora palmivora isolates from cacao. Canadian Journal of Botany, v.56, p.1730-1738, 1978.

KERVINEN, T.; PELTRONEN, S.; TEERI, T.H.; KARJALAINEN, R. Differential expression of phenylalanine ammonia-lyase genes in barley induced by fungal infection or elicitors. New Phytologist, v.139, p.293-300, 1998.

KOBAYASHI, S.; UCHIMIYA, H. Expression and integration of a foreign gene in orange (Citrus sinensis L. Osbeck) protoplasts by direct DNA transfer. Japanese Journal of Genetics, v.64, p.91-97, 1989.

KREBS, M.P.; KHORANA, H.G. Mechanism of light-dependent proton translocation by bacteriodopisin. Journal of Bacteriology, v.175, n.6, p.1555-1560, 1993.

LARANJEIRA, F.F. Dez anos de clorose variegada dos citros: o que sabemos? Laranja, v.18, n.1, p.123-141, 1997.

LEITE JUNIOR, R.P.; BESPALHOK, J.C.; VIEIRA, L.G.E. Desenvolvimento de plantas transgênicas de citros para obtenção de resistência a doenças. In: SEMINÁRIO INTERNACIONAL DE CITROS, 7., Bededouro (Brasil), 2002. Resumos. Bebedouro: EECB, 2002. p.74-81: Melhoramento.

LEVEE, V.; SEGUIN, A. Inducible expression of the herologous PAL2 promoter from bean in white pine (Pine strobes) transgenic cells. Tree Physiology, v.21, p.665-672, 2001.

McNELLIS, T.W.; MUDGEU, M.B.; LI, M.B.; AOYAMA, T.; HORTWATH, T.; CHUA, D.; STSKAWICZ, B.J. Glucocorticoid-inducible expression of a bacterial avirulence gene in transgenic Arabidopsis induces hypersensitive cell death. Plant Journal, v.14, p.247-257, 1998. 
MEDINA FILHO, H.P.; BORDIGNON, R.; SIQUEIRA, W.J.; FEICHTENBERGER, E.; CARVALHO, M.R.T. Tolerância de híbridos e clones de porta-enxertos de citros à infecção de raízes por Phytophthora nicotianae. Fitopatologia Brasileira, v.28, n.5, p.534-540, 2004.

MENDES, B.M.J.; BOSCARIOL, R.L.; MOURÃO FILHO, F.A.A.; ALMEIDA, W.A.B. Agrobacterium-mediated tranformation of citrus Hamlin cultivar (Citrus sinensis L. Osbeck) epicotil segments. Pesquisa Agropecuária Brasileira, v.37, n.7, p.955-961, 2002.

MITTLER, R.; LAM, E. Sacrifice in the face of foes: pathogen-induced programmed cell death in higher plants. Trends Microbiology, v. 4, p.10-15, 1996.

MITTLER, R.; RIZHSKY, L. Transgene-induced lesion mimic. Plant Molecular Biology, v. 44, p.335-344, 2000.

MITTLER, R.; SHULAEV, V.; LAM, E. Coordinated activation of programmed cell death and defense mechanisms in transgenic tobacco plants expressing a bacterial proton pump. The Plant Cell, v.7, p.29-42, 1995.

MOHAMED, R.; MEILAN, R.; OSTRY, M.E.; MICHLER, C.H.; STRAUSS, S.H. Bacterio-opsin gene overexpression fails to elevate fungal disease in transgenic poplar (Populus). Canadian Journal of Forest Research, v.31, p.268-275, 2001.

MONTANELLI, C.; NASCARI, G. Introduction of an antibacterial gene in potato (Solanum tuberosum L.) using a binary vector in Agrobacterium rhizogenes. Journal of Genetic Breeding, v.45, p. 307-316, 1991.

MOORE, G.A.; JACONO, C.C.; NEIDIGH, J.L.; LAWRENCE, S.D.; CLINE, K. Agrobacterium-mediated transformation of citrus stem segments and regeneration of transgenic plants. Plant Cell Reports, v.11, p.238-242, 1992. 
MOREIRA, C.S.; PIO, R.M. Melhoramento de citros. In: RODRIGUEZ, O.; VIEGAS, F.; POMPEU JÚNIOR, J.; AMARO, A.A. (Coord.). Citricultura brasileira. Campinas: Fundação Cargill, 1991. v.1, p.116-144.

MOURGUES, F.; BRISSET, M.; CHEVREAU, E. Strategies to improve plant resistance to bacterial diseases through genetic engineering. Trends in Biotechnology, v.6, p. 203-210, 1998.

MÜLLER, G.; COSTA, A.S. Doenças causadas por vírus, viróides e similares em citros. In: RODRIGUEZ, O.; VIEGAS, F.; POMPEU JÚNIOR, J.; AMARO, A.A. (Coord). Citricultura brasileira. Campinas: Fundação Cargill, 1991. v.1, p.735757.

MULLER, G.; DE NEGRI, D. Nova doença nos pomares: Morte súbita dos citros. Citricultura Atual, v.5, n.25, p.12-13, 2001.

MURASHIGE, T.; TUCKER, D.P.H. Growth factor requirement of citrus tissue culture. In: INTERNATIONAL CITRUS SYMPOSIUM, 1. Riverside, 1969. Univ. of California, Riverside: ISC, Proceedings.1969. v.3, p.1155-1169.

NAVARRO, L.; OLIVARES-FUSTER, O.; JUÁREZ,J.; ALEZA, P.; PINA, J.A.; CERVERA, M.; FAGOAGA, C.; PÉREZ, R.M.; PEÑA, L. Melhoramento de citros na Espanha através da regeneração de triplóides, hibridação somática e transformação genética. In: SEMINÁRIO INTERNACIONAL DE CITROS, 7, Bebedouro, 2002. Anais. Bebedouro: EECB, SBF, 2002. p. 57-70: Melhoramento

NORELLI, J.L.; ALDWINCKLE, H.S.; DESTEFANO-BELTRAN, L.; JAYNES, J.M. Transgenic Malling 26 apple expressing the attacin E gene has increased resistance to Erwinia amylovora. Euphytica, v.77, p.123-128, 1994.

OGER, P.; PETIT, A.; DESSAUX, Y. Genetically engineered plants producing opines alter their biological environment. Nature Biotechnology, v.15, p.369-372, 1997. 
OHI, S.; HELDRICK, S.A.; CHORY, J.; LAMB, C.J. Functional properties of a phenylalanine ammonia-lyase promoter from Arabidopsis. The Plant Cell, v.2, p.837-848, 1990.

OHSHIMA, M.; MITSUHARA, I.; OKAMOTO, M.; SAWANO, S.; NISHIYAMA, K.; KAKU, H.; NATORI, S.; OHASHI, Y. Enhanced resistance to bacterial diseases of transgenic tobacco plants overexpressing sarcotoxin IA, a bactericidal peptide of insect. Journal of Biochemistry, v.124, n.4 p. 431-435, 1999.

OWENS, L.D.; HEUTTE, T.M. A single amino acid substituition in the antimicrobial defense protein cecropin $\mathrm{B}$ is associated with diminished degradation by leaf intercellular fluid. Molecular Plant-Microbe Interactions, v.10, p.525-528, 1997.

PALAZZO, D.A.; CARVALHO, M.L.V. Desenvolvimento e progresso da clorose variegada dos citros (CVC) em pomares de Colina, SP. Laranja, v.13, n.2, p.489502, 1992.

PEÑA, L.; CERVERA, M.; JUÁREZ, J.; NAVARRO, A.; PINA, J.A.; NAVARRO, L. Genetic transformation of lime (Citrus aurantifolia Swing.): factors affeting transformation and regeneration. Plant Cell Reports, v.16, p.731-737, 1997.

PEÑA， L.; MARTÍN-TILLO, M.; JUÁREZ, J.; PINA， J.A.; NAVARRO, L.; MARTÍNEZ-ZAPATER, M. Constitutive expression of Arabidopsis LEAFY OR APETALA1 genes in citrus reduces their generation time. Nature, v.19, p.263-267, 2001.

PEÑA, L.; CERVERA, M.; JUÁREZ, J.; NAVARRO, A.; PINA, J.A.; DURÁN-VILA, N.; NAVARRO, L. Agrobacterium-mediated transformation of sweet orange and regeneration of transgenic plants. Plant Cell Reports, v.14, p.616-619, 1995. 
PÉREZ-MOLPHE-BALCH, E.; OCHOA-ALEJO, N. Regeneration of transgenic plants of Mexican lime from Agrobacterium rhizogenes-transformed tissues. Plant Cell Reports, v.17, p.591-596, 1998.

POMPEU JÚNIOR, J. Rootstocks and scions in the citriculture of de São Paulo State. In: INTERNATIONAL CONGRESS OF CITRUS NURSERYMEN, 6, Ribeirão Preto, 2001. Proceedings. Ribeirão Preto: EECB/Fundecitrus, 2001. p. 75-82.

POMPEU JÚNIOR, J.; LARANJEIRA, F.F.; HARAKAVA, R.; FIGUEIREDO, J.O. de; CARVALHO, S.A.; COLETTA FILHO, H.D. Detecção de sintomas de clorose variegada dos citros e Xylella fastidiosa em plantas cítrica infectadas em condição de campo. Laranja, v.19, n.2, p.321-330, 1998.

QUECINI, V.M.; VIEIRA, M.L.C. Plantas transgênicas. In: SERAFINI, L.A.; NEIVA MONTEIRO DE BARROS, N.M.; AZEVEDO, J.L. Biotecnologia na agricultura e na agroindústria. Guaíba : Agropecuária, 2001. p.278-331.

REED, J.; EDWARDS, D.L.; GONZALES, C.F. Synthetic peptide combinatorial libraries: A method for the identification of bioactive peptides against phytopathogenic fungi. Molecular Plant-Microbe Interactions, v.10, p.537-549, 1997.

RIZHSKY, L.; MITTLER, R. Inducible expression of bacterio-opsin in transgenic tabacco and tomato plants. Plant Molecular Biology, v.46, p.313-323, 2001.

ROOKES, J.E.; CAHILL, D.M. A PALL1 gene promoter-green fluorescent protein reporter system to analyse defence responses in live cells of Arabidopsis thaliana. European Journal of Plant Pathology, v.109, p.83-94, 2003.

ROSSETTI, V. Estudos sobre “gomose de Phytophthora” dos citros I. Suscetibilidade de diversas espécies cítricas à algumas espécies de Phytophthora. Arquivos do Instituto Biológico, v.18, p.97-124, 1947. 
ROSSETTI, V. Clorose Variegada dos Citros (CVC). In: RODRIGUEZ, O.; VIEGAS, F.; POMPEU JÚNIOR, J.; AMARO, A.A. (Coord.). Citricultura brasileira. Campinas: Fundação Cargill, v.2, p.715-720., 1991.

SAKUTA, C.; ODA, A.; YAMAKAWA, S.; SATOH, S. Root-specific expresion of genes for novel glycine-rich proteins cloned by use of an antiserum against xylem sap protein of cucumber. Plant Cell Physiology, v.39, p.1340-1340, 1998.

SALVA, R. Citrus tree production in Brazil. In: INTERNATIONAL CONGRESS OF CITRUS NURSERYMEN, 6, Ribeirão Preto, 2001. Proceedings. Ribeirão Preto: EECB/Fundecitrus, 2001. p. 11-16.

SHARMA, A.; SHARMA, R.; IMAMURA, M.; MACHILI, H. Transgenic expression of cecropin $\mathrm{B}$ an antibacterial peptide from Bombix mori, confers enhanced resistance to bacterial leaf blight rice. FEBS, v.484, p.7-11, 2000.

SHENG, J.; CITOVSKY, V. Agrobacterium-plant cell DNA transport: Have virulence proteins, will travel. The Plant Cell, v.8, p.1699-1710, 1996.

SHUFFLEBOTTOM, D.; EDWARDS, K.; SCHUCK, W.; BEVAN, M. Transcription of 2 members of a gene 1 family encoding phenylalamine ammonia-lyase leads to remarkably different cell specificities and induction-patterns. Plant Journal, v.3, p.835-845, 1993.

SIVIEIRO, A.; BOAVA, L.; FURTADO, E.L.; MASUDA, Y.; MACHADO, M.A. Avaliação precoce de gomose de Phytophthora em plantas jovens de citros. Fitopatologia Brasileira, v.25, p.425, 2000.

SIVIERO, A.; FURTADO, E.L.; BOAVA, L.P.; BARBASSO, D.V.; MACHADO, M.A. Avaliação de métodos de inoculação de Phytophthora parasitica em plântulas plantas jovens de citros. Fitopatologia Brasileira, v.27, n.6, p. 574-580, 2002. 
SMITH, R.A.; DRUMIND, S.; HAINES, A.; OIRTER, J.R.; HOCK, R.S. Induction of umbelliferone in sweet potato cell suspension culture using mercuric chloride. Biotechnology Letters, v.23, p.1397-1400, 2001.

SPIEGEL-ROY, P.; VARDI, A. Citrus. In: AMIRATO, P.V.; EVANS, D.A.; SHAM, W.R.; YAMADA, Y. (Ed.) Handbook of plant cell culture. New York: Macmillan, 1984, cap.13, p.355-372.

STACHEL, S.E.; MESSENS, E.; VAN MONTAGU, M.; ZAMBRYSKI, P. Identification of the signal molecules produced by wounded plant cells that activate T-DNA transfer in Agrobacterium tumefaciens. Nature, v.318, p.624-629, 1985.

STEINER, H.; ANDREU, D.; MERRIFIELD, R.B. Binding and action of cecropin analogues: antibacterial peptides from insects. Biochimica et Biophysica Acta, v.939, p. 260-266, 1981

TEMPÉ, J.; SCHELL, J. Is crown gall a natural instance of gene transfer? In: LEGOCKI, A.B. (Ed.). Translation of natural and synthetic polynucleotides. New York: Elsevier Publishers, 1977. p.415-427.

TIMMER, L.W.; GARNSEY, S.M.; GRAHAM, J.M. Compedium of citrus diseases. St. Paul:APS Press, 2000. 80p.

TIMMER, N.E.; HWANG, D.; BONNESS, M. C-terminal deletion mutant of pokweed antiviral protein inhibits viral infection but does not depurinate ribosomes. Proceedings National Academic of Sciencie, v.94, p.3866-3871, 1997.

TINLAND, B. The integration of T-DNA into plant genomes. Trends in Plant Science, v.1, p.178-183, 1996.

TURGEON, R. Teratomas and secondary tumors. In: KAHL, G.; SCHELL, J.S. (Ed). Molecular biology of plants tumors. New York: Academic Press, 1982. p.391-414. 
VALE, F.X.R.; FERNANDES FILHO, E.I.; LIBERATO, J.R.; ZAMBOLIM, L. QuantA software to quantify plant disease severity. In: INTERNACIONAL WORKSHOP ON PLANT DiSEASE EPIDEMIOLOGY, 8., Ouro Preto, 2001. Proceedings. Ouro Preto: Internatinal Society of Plant Phatology, 2001. p.160.

VARDI, A.; GALUN, E.; FRYDMAN-SHANI, A.; GONEN, P.; BLIECHMAN, S. Citrus cybrids: transfer of Microcitrus organelles into Citrus cultivars. Acta Horticulturae, v.280, p.239-245, 1990.

WAARA, S.; GLIMELIUS, K. The potential of somatic hibridization in crop breeding. Euphytica, v.85, p.21-33, 1995.

WANG, G.L.; SONG, W.Y.; RUAN, D.L.; SIDERIS, S.; RONALD, P.C. The cloned gene, Xa21, confers resistance to multiple Xanthomonas oryzae pv. oryzae isolates in transgenic plants. Molecular Plant-Microbe Interaction, v.9, n.9, p.850-855, 1996.

WANG, K.; HERRERA-ESTRELLA, L.; VAN MONTAGU, M.; ZAMBRYSKI, P. Right 25-bp terminus of the nopaline T_DNA is essential for and determines direction of DNA transfer from Agrobacterium to the plant genome. Cell, v.38, p.455-462, 1984.

WANNER, L.A.; GUOQING, L.; WARE, D.; SOMSSICH, I.E.; DAVIS, K.R. The phenylalamine ammonia-lyase gene family in Arabidopsis thaliana. Plant Molecular Biology, v.27, p.327-338, 1996.

WHITESIDE, J.O, S.M. GARNSEY; L.W. TIMMER. Compendium of citrus diseases. St Paul: Aps Press., 2 ed., 1993. 80p.

WIDMER, T.L.; GRAHAM, J.H.; MITCHELL, D.J. Histological comparasion of fibrous root infection of desease- tolerant and susceptible citrus hosts by Phytophthora nicotianae and P. palmivora. Phytopathology, v.88, p.389-395, 1998. 
WONG, W.S.; LI, G.G.; NING, W.; XU, Z.F.; HSIAO, W.L.W.; ZHANG, L.Y.; LI, N. Repression of chilling-induced ACC accumulation in transgenic citrus by overproduction of antisense 1-aminocyclopropane-1-carboxylate synthase RNA. Plant Science, v.161, p.969-977, 2001.

YALPANI, N.; SILVERMAN, P.; WILSON, T.M.A.; KLEIER, D.A.; RASKIN, I. Salicylic acid is a systemic signal and an inducer of pathogenesis-related proteins in virus-infected tobacco. The Plant Cell, v.3, p.809-818, 1991.

YAO, J.L.; WU, J.H.; GLEAVE, A.P.; MORRIS, B.A.M. Transformation of citrus embryogenic cells using particle bombardment and production of transgenic embryos. Plant Science, v.113, p.175-183, 1996.

ZAMBRYSKI, P.C. Chronicles from the Agrobacterium-plant cell DNA transfer story. Annual Review of Plant Physiology and Plant Molecular Biology, v.43, p.465490, 1992.

ZASLOFF, M. Antimicrobial peptides of multicellular organisms. Nature, v.415, p.389395, 2002.

ZHU, Q.; DABI, T.; BEECHE, A.; YAMAMOTO, R.; LAWTON, M.A.; LAMB, C. Cloning and properties of a rice gene encoding phenylalamine ammonia-lyase. Plant Biology, v.29, p.535-550, 1995.

ZOUBENKO, O.; UCKUN, F.; HUR, Y.; CHET, I.; TUMER, N. Plant resistance to fungal infection induced by nontoxic pokweed antiviral protein mutants. Nature Biotechnology, v.15, p.992-996, 1997.

ZOUBENKO, O.; UDAK, K.; TUMER, N. A non-toxic pokweed antiviral protein mutant inhibts pathogen infection via a novel salicylic acid-independent pathway. Plant Molecular Biology, v.44, p.219-229, 2000. 
ZUBRZYCKI, H.M. Produção de frutas cítricas no nordeste argentino na presença do cancro cítrico (Xanthomonas axonopodis pv. citri). SEMINÁRIO INTERNACIONAL DE CITROS, 5, Bebedouro, 1998. Anais. Bebedouro: Fundação Cargill, 1998. p. 251-272: tratos Culturais.

ZUPAN, J.; ZAMBRYSKI, P. Transfer of T-DNA from Agrobacterium to the plant host cell. Plant Physiology, v.107, p.1041-1047, 1995. 
APÊNDICE 
APÊNDICE 1- MEIOS DE CULTURA

Soluções estoque do meio MT (Murashige \& Tucker, 1969)

MT Macronutrientes estoque (50x)

g. $\mathbf{L}^{-1}$

$\mathrm{NH}_{4} \mathrm{NO}_{3}$

82,5

$\mathrm{KNO}_{3}$

95,0

$\mathrm{MgSO}_{4} \cdot 7 \mathrm{H}_{2} \mathrm{O}$

18.5

$\mathrm{KO}_{2} \mathrm{PO}_{4}$

7,5

$\mathrm{K}_{2} \mathrm{HPO}_{4}$

1,0

MT Micronutrientes estoque (100x)

g. $\mathbf{L}^{-1}$

$\mathrm{H}_{3} \mathrm{BO}_{3}$

$\mathrm{MnSO}_{4} \cdot \mathrm{H}_{2} \mathrm{O}$

1,68

$\mathrm{ZnSO}_{4} \cdot 7 \mathrm{H}_{2} \mathrm{O}$

0,86

$\mathrm{KI}$

0,083

$\mathrm{NaMoO}_{4} \cdot 2 \mathrm{H}_{2} \mathrm{O}$

0,025

$\mathrm{CuSO}_{4} \cdot 5 \mathrm{H}_{2} \mathrm{O}$

0,0025

$\mathrm{CoCl}_{2} \cdot 6 \mathrm{H}_{2} \mathrm{O}$

0,0025

MT Ferro estoque (200x)

g. $\mathrm{L}^{-1}$

$\mathrm{Na}_{2}$ EDTA

7,45

$\mathrm{FeSO}_{4} .7 \mathrm{H}_{2} \mathrm{O}$

5,57 
MT Vitaminas estoque (100x)

g.L -1 $^{-1}$

Myo-inositol 10,0

Tiamina-HCL 1,0

Pyridoxina-HCL 1,0

Ácido nicotínico 0,5

Glicina 0,2

MT Cálcio estoque (66x) g.L L $^{-1}$

$\mathrm{CaCl}_{2} \cdot 2 \mathrm{H}_{2} \mathrm{O}$ 22,0

Meio de cultura MT (Murashige \& Tucker, 1969) mL. $\mathbf{L}^{-1}$

MT Macronutrientes estoque (50x) 20,0

MT Micronutrientes estoque (100x) 10,0

MT Vitaminas estoque (100x) 10,0

MT Cálcio estoque (66x) 15,0

MT Ferro estoque (200x) 5,0

g. $\mathbf{L}^{-1}$

Sacarose 25

Agar

8

Obs: o pH do meio foi ajustado para 5.8, antes de adicionar o Agar, e foi autoclavado por 20 minutos $\left(121^{\circ} \mathrm{C}\right.$ e $\left.1,0 \mathrm{Kg} \cdot \mathrm{cm}^{-2}\right)$. 
Meio de YEP Sólido

Peptona

$\mathrm{NaCl}$

Agar

Meio de YEP Líquido

$\mathrm{NaCl}$

Obs: $\mathrm{pH}$ do meio foi ajustado para 7.0 antes de adicionar o Agar e autoclavado por 20 minutos $\left(121^{\circ} \mathrm{C}\right.$ e $\left.1,0 \mathrm{Kg} . \mathrm{cm}^{-2}\right)$.

\section{Meio CA - Cenoura Agar}

Obs: autoclavar à $121^{\circ} \mathrm{C}$ por 20 minutos. 
MT Vitaminas estoque (100x) g.L L $^{-1}$

Myo-inositol 10,0

Tiamina-HCL 1,0

Pyridoxina-HCL 1,0

Ácido nicotínico 0,5

Glicina 0,2

MT Cálcio estoque (66x) g. $\mathrm{L}^{-1}$

$\mathrm{CaCl}_{2} \cdot 2 \mathrm{H}_{2} \mathrm{O}$ 22,0

\section{MT}

MT Macronutrientes estoque (50x)

20,0 mL.L ${ }^{-1}$

MT Micronutrientes estoque (100x)

10,0 mL.L ${ }^{-1}$

MT Vitaminas estoque (100x)

10,0 mL.L ${ }^{-1}$

MT Cálcio estoque (66x)

15,0 mL. $\mathrm{L}^{-1}$

MT Ferro estoque (200x)

$5,0 \mathrm{~mL} . \mathrm{L}^{-1}$

Sacarose

25 g. $^{-1}$

Agar

8 g.L ${ }^{-1}$

\section{EME}

MT Macronutrientes estoque (50X)

20 ml.. ${ }^{-1}$

MT Micronutrientes estoque (100X)

$10 \mathrm{ml} . \mathrm{L}^{-1}$

MT Vitaminas estoque (100X)

10 ml.L ${ }^{1}$

MT Cálcio estoque (50X)

$20 \mathrm{ml} . \mathrm{L}^{-1}$

Obs: todos os meios de cultura tiveram o $\mathrm{pH}$ ajustado para 5,8, antes de adicionar o Agar, e foram autoclavados por 20 minutos $\left(121^{\circ} \mathrm{C}\right.$ e $\left.1,0 \mathrm{Kg} / \mathrm{cm}^{2}\right)$. 
YEP Sólido

g.L -1 $^{-1}$

Peptona

10,0

Extrato de Levedura

10,0

$\mathrm{NaCl}$

5,0

Agar

15,0

Obs: ajustar pH para 7,0 antes de adicionar o Agar e autoclavar por 20 minutos $\left(121^{\circ} \mathrm{C} \mathrm{e}\right.$ $\left.1,0 \mathrm{Kg} / \mathrm{cm}^{2}\right)$.

YEP Líquido

Peptona

Extrato de Levedura 10,0

$\mathrm{NaCl}$

5,0

Obs: ajustar pH para 7,0 antes de adicionar o Agar e autoclavar por 20 minutos $\left(121^{\circ} \mathrm{C} \mathrm{e}\right.$ $\left.1,0 \mathrm{Kg} / \mathrm{cm}^{2}\right)$.

\section{Meio CA - Cenoura Agar}

200 g. de cenoura triturada e peneirada

20 g. de ágar

1 litro de água destilada

Autoclavado à $121^{\circ} \mathrm{C}$ por $15 \mathrm{~m}$ 